U.S. Department of the Interior

U.S. Geological Survey

\title{
Evaluation of Borehole Geophysical Logs and Hydraulic Tests, Phase III, at AIW Frank/Mid-County Mustang Superfund Site, Chester County, Pennsylvania
}

by Ronald A. Sloto

Water-Resources Investigations Report 01-4004 


\section{U.S. DEPARTMENT OF THE INTERIOR \\ GALE A. NORTON, Secretary}

\section{U.S. GEOLOGICAL SURVEY \\ Charles G. Groat, Director}

For additional information

write to:

District Chief

U.S. Geological Survey

215 Limekiln Road

New Cumberland, Pennsylvania 17070-2424
Copies of this report may be

purchased from:

U.S. Geological Survey

Branch of Information Services

Box 25286

Denver, Colorado 80225-0286 


\section{CONTENTS}

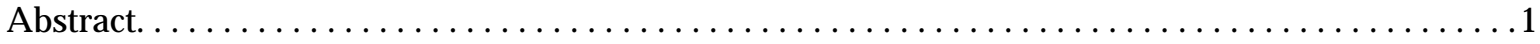

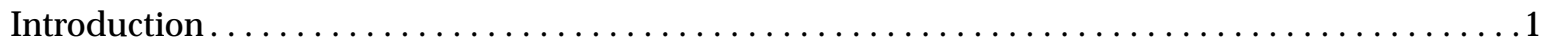

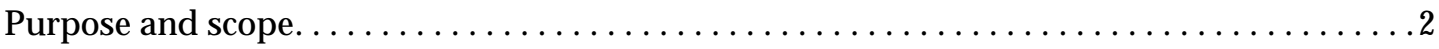

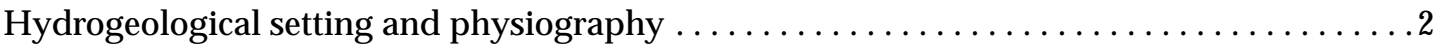

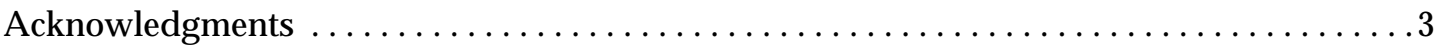

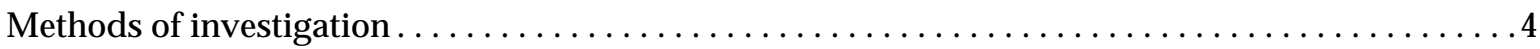

Borehole geophysical methods . ................................

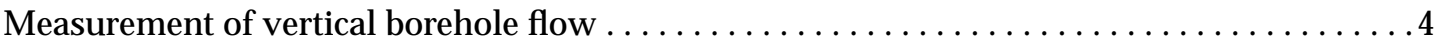

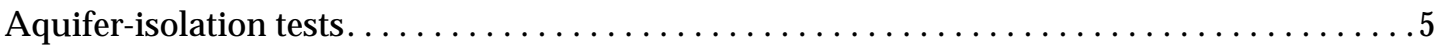

Evaluation of borehole geophysical logs and aquifer-isolation tests $\ldots \ldots \ldots \ldots \ldots \ldots \ldots \ldots 7$

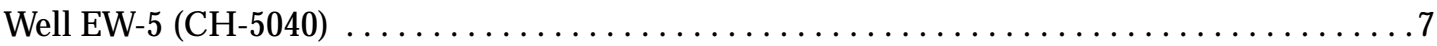

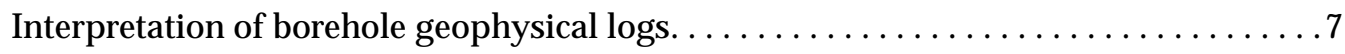

Aquifer-isolation tests . . . . . . . . . . . . . . . . . . . . . . . . . .

Aquifer-isolation test of interval 1 (257 to 298 feet below land surface) . . . . . 9

Aquifer-isolation test of interval 2 (194 to 298 feet below land surface) . . . . . 10

Aquifer-isolation test of interval 3 (63 to 80 feet below land surface) ........11

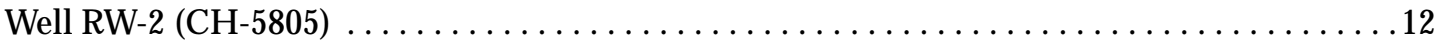

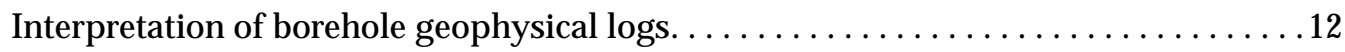

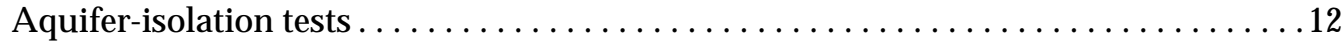

Aquifer-isolation test of interval 1 (160 to 184 feet below land surface) . . . . . 14

Aquifer-isolation test of interval 2 (90 to 105 feet below land surface) . . . . . .15

Aquifer-isolation test of interval 3 (61 to 76 feet below land surface) . . . . . . 16

Aquifer-isolation test of interval 4 (45 to 60 feet below land surface) . . . . . . .17

Aquifer-isolation test of interval 5 (30 to 45 feet below land surface) . ......18

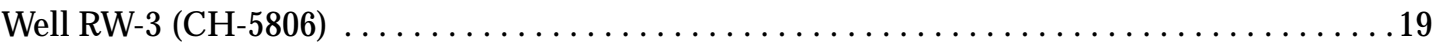

Interpretation of borehole geophysical logs. ...................... 19

Aquifer-isolation tests . . . . . . . . . . . . . . . . . . . . . . . . 19

Aquifer-isolation test of interval 1 (164 to 198 feet below land surface) . . . . .21

Aquifer-isolation test of interval 2 (148 to 167 feet below land surface) . . . . .22

Aquifer-isolation test of interval 3 (109 to 128 feet below land surface) . .....23

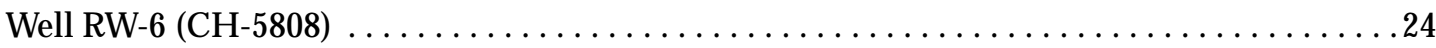

Interpretation of borehole geophysical logs........................ 24

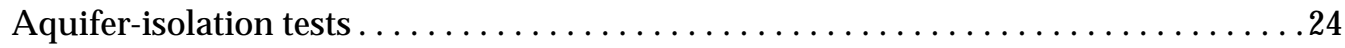

Aquifer-isolation test of interval 1 (197 to 216 feet below land surface) . . . . .26

Aquifer-isolation test of interval 2 (177 to 196 feet below land surface) . . . . .27

Aquifer-isolation test of interval 3 (106 to 125 feet below land surface) . . . . 27

Aquifer-isolation test of interval 4 (80 to 99 feet below land surface) . . . . . . 29

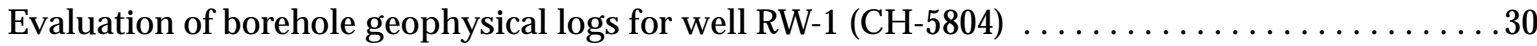

Evaluation of borehole geophysical logs for well RW-4 $(\mathrm{CH}-5807) \ldots \ldots \ldots \ldots \ldots \ldots \ldots \ldots \ldots \ldots$

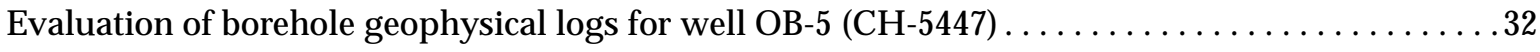

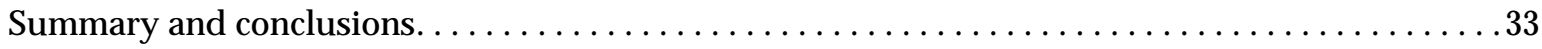

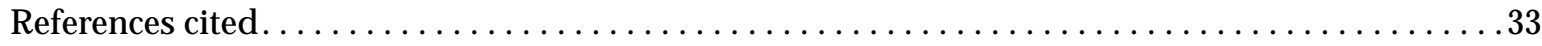




\section{ILLUSTRATIONS}

Figure 1. Map showing location of the boreholes where geophysical logging and aquifer-isolation tests were conducted, AIW Frank/Mid-County Mustang Superfund Site, Chester County, Pennsylvania.................... 2

2. Generalized sketch of straddle-packer assembly and pump in borehole........6

3. Graphs showing borehole geophysical logs from well EW-5 (CH-5040), AIW Frank/Mid-County Mustang Superfund Site $\ldots \ldots \ldots \ldots \ldots \ldots . \ldots$

4. Hydrographs from aquifer-isolation test of interval 1 (257 to 298 feet below land surface) in well EW-5 (CH-5040), AIW Frank/Mid-County Mustang

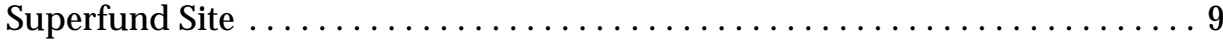

5. Hydrographs from aquifer-isolation test of interval 2 (194 to 298 feet below land surface) in well EW-5 (CH-5040), AIW Frank/Mid-County Mustang

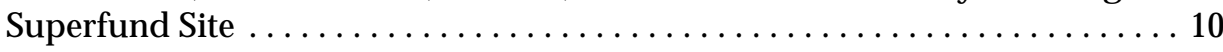

6. Hydrographs from aquifer-isolation test of interval 3 (63 to 80 feet below land surface) in well EW-5 (CH-5040), AIW Frank/Mid-County Mustang

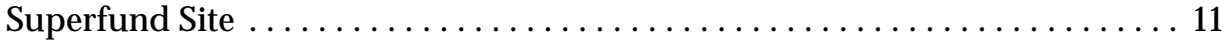

7. Graphs showing borehole geophysical logs from well RW-2 (CH-5805), AIW Frank/Mid-County Mustang Superfund Site . .................. 13

8. Hydrographs from aquifer-isolation test of interval 1 (160 to 184 feet below land surface) in well RW-2 (CH-5805), AIW Frank/Mid-County Mustang

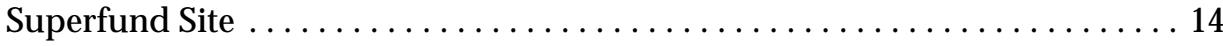

9. Hydrographs from aquifer-isolation test of interval 2 (90 to 105 feet below land surface) in well RW-2 (CH-5805), AIW Frank/Mid-County Mustang

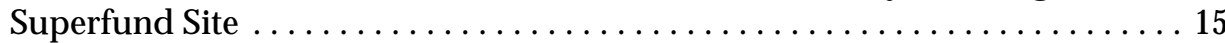

10. Hydrographs from aquifer-isolation test of interval 3 (61 to 76 feet below land surface) in well RW-2 (CH-5805), AIW Frank/Mid-County Mustang

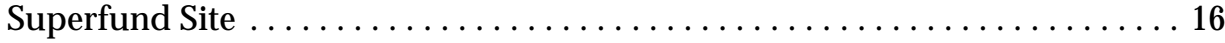

11. Hydrographs from aquifer-isolation test of interval 4 (45 to 60 feet below land surface) in well RW-2 (CH-5805), AIW Frank/Mid-County Mustang

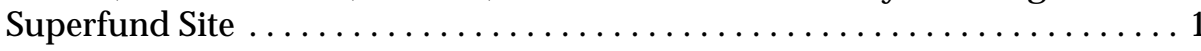

12. Hydrographs from aquifer-isolation test of interval 5 (30 to 45 feet below land surface) in well RW-2 (CH-5805), AIW Frank/Mid-County Mustang

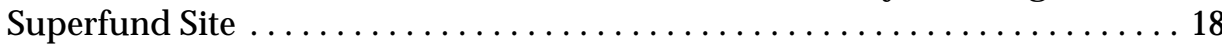

13. Graphs showing borehole geophysical logs from well RW-3 (CH-5806), AIW Frank/Mid-County Mustang Superfund Site $\ldots \ldots \ldots \ldots \ldots \ldots \ldots$

14. Hydrographs from aquifer-isolation test of interval 1 (164 to 198 feet below land surface) in well RW-3 (CH-5806), AIW Frank/Mid-County Mustang

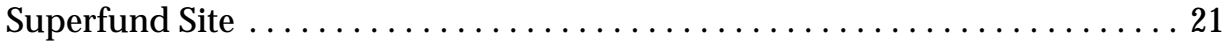




\section{ILLUSTRATIONS-Continued}

Figure 15. Hydrographs from aquifer-isolation test of interval 2 (148 to 167 feet below land surface) in well RW-3 (CH-5806), AIW Frank/Mid-County Mustang

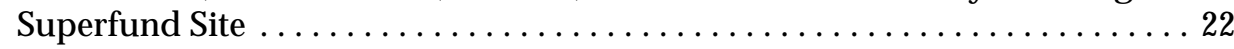

16. Hydrographs from aquifer-isolation test of interval 3 (109 to 128 feet below land surface) in well RW-3 (CH-5806), AIW Frank/Mid-County Mustang

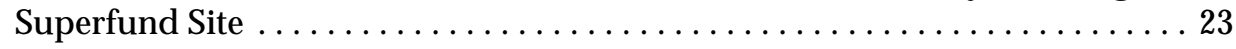

17. Graphs showing borehole geophysical logs from well RW-6 (CH-5808), AIW Frank/Mid-County Mustang Superfund Site ............... 25

18. Hydrographs from aquifer-isolation test of interval 1 (197 to 216 feet below land surface) in well RW-6 (CH-5808), AIW Frank/Mid-County Mustang

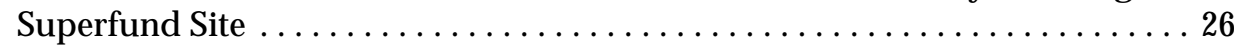

19. Hydrographs from aquifer-isolation test of interval 2 (177 to 196 feet below land surface) in well RW-6 (CH-5808), AIW Frank/Mid-County Mustang

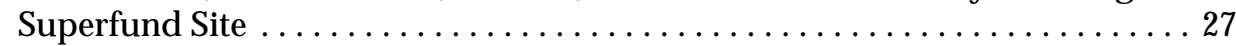

20. Hydrographs from aquifer-isolation test of interval 3 (106 to 125 feet below land surface) in well RW-6 (CH-5808), AIW Frank/Mid-County Mustang

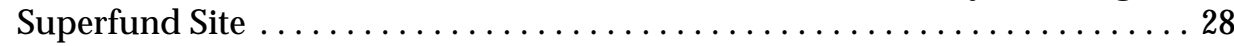

21. Hydrographs from aquifer-isolation test of interval 4 (80 to 99 feet below land surface) in well RW-6 (CH-5808), AIW Frank/Mid-County Mustang Superfund Site

22-24. Graphs showing:

22. Borehole geophysical logs from well RW-1 (CH-5804), AIW Frank/Mid-

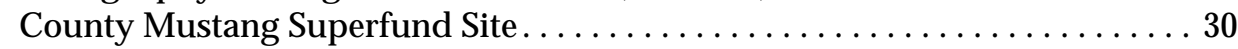

23. Borehole geophysical logs from well RW-4 (CH-5807), AIW Frank/MidCounty Mustang Superfund Site ........................ 31

24. Borehole geophysical logs from well OB-5 (CH-5447), AIW Frank/Mid-

County Mustang Superfund Site .......................... 32 


\section{TABLES}

Table 1. Boreholes logged at the AIW Frank/Mid-County Mustang Superfund Site,

Chester County, Pennsylvania . . . . . . . . . . . . . . . . . . . . . 3

2. Intervals isolated and specific capacities for well EW-5 (CH-5040), AIW Frank/

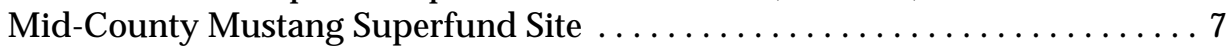

3. Fracture dip and azimuth determined with the acoustic borehole televiewer for water-bearing fractures in well RW-2 (CH-5805), AIW Frank/Mid-County Mustang Superfund Site ............................... 12

4. Heatpulse-flowmeter measurements made in well RW-2 (CH-5805), AIW Frank/Mid-County Mustang Superfund Site $\ldots \ldots \ldots \ldots \ldots \ldots \ldots \ldots \ldots \ldots$

5. Intervals isolated and specific capacities for well RW-2 (CH-5805), AIW Frank/ Mid-County Mustang Superfund Site $\ldots \ldots \ldots \ldots \ldots \ldots \ldots \ldots \ldots \ldots \ldots \ldots \ldots \ldots$

6. Heatpulse-flowmeter measurements made in well RW-3 (CH-5806), AIW Frank/Mid-County Mustang Superfund Site . . . . . . . . . . . . . . . 19

7. Intervals isolated and specific capacities for well RW-3 (CH-5806), AIW Frank/ Mid-County Mustang Superfund Site $\ldots \ldots \ldots \ldots \ldots \ldots \ldots \ldots . \ldots . \ldots . \ldots 19$

8. Heatpulse-flowmeter measurements made in well RW-6 (CH-5808), AIW Frank/Mid-County Mustang Superfund Site ................... 24

9. Intervals isolated and specific capacities for well RW-6 (CH-5808), AIW Frank/ Mid-County Mustang Superfund Site $\ldots \ldots \ldots \ldots \ldots \ldots \ldots \ldots . \ldots . \ldots . \ldots 24$

\section{CONVERSION FACTORS AND ABBREVIATIONS}

\begin{tabular}{lcl} 
Multiply & By & To obtain \\
& $\underline{\text { LENGTH }}$ & millimeter \\
inch (in.) & 25.4 & meter \\
foot $(\mathrm{ft})$ & 0.3048 & hectare \\
acre & 0.4047 & liter \\
& $\underline{\text { VOLUME }}$ & \\
gallon (gal) & 3.785 & liter per second \\
& $\underline{\text { FLOW }}$ & \\
gallon per minute $(\mathrm{gal} / \mathrm{min})$ & 0.06309 & liter per second per meter \\
gallon per minute per foot $[(\mathrm{gal} / \mathrm{min}) / \mathrm{ft}]$ & 0.2070 & \\
& SPECIFIC CAPACITY & \\
\hline
\end{tabular}




\title{
Evaluation of Borehole Geophysical Logs AND HydRaUlic TESTS, PHASE III, at AIW Frank/Mid-County Mustang SUPERfund Site, Chester County, Pennsylvania
}

\author{
By Ronald A. Sloto
}

\section{ABSTRACT}

Borehole geophysical logs, heatpulse-flowmeter measurements, and aquifer-isolation tests were used to characterize the ground-water-flow system at the AIW Frank/Mid-County Mustang Superfund Site. The site is underlain by fractured carbonate rocks. Caliper, natural-gamma, single-point-resistance, fluid-resistivity, and fluid-temperature logs were run in six wells, and an acoustic borehole televiewer and borehole deviation log was run in one well. The direction and rate of borehole-fluid movement was measured with a high-resolution heatpulse flowmeter for both nonpumping and pumping conditions in four wells. The heatpulse-flowmeter measurements showed flow within the borehole during nonpumping conditions in three of the four wells tested. Flow rates up to 1.4 gallons per minute were measured. Flow was upward in one well and both upward and downward in two wells. Aquifer-isolation (packer) tests were conducted in four wells to determine depth-discrete specific capacity values, to obtain depth-discrete water samples, and to determine the effect of pumping an individual fracture or fracture zone in one well on water levels in nearby wells. Water-level data collected during aquifer-isolation tests were consistent with and confirmed interpretations of borehole geophysical logs and heatpulse-flowmeter measurements. Seven of the 13 fractures identified as water-producing or water-receiving zones by borehole geophysical methods produced water at a rate equal to or greater than 7.5 gallons per minute when isolated and pumped. The specific capacities of isolated fractures range over three orders of magnitude, from 0.005 to 7.1 gallons per minute per foot. Vertical distribution of specific capacity between land surface and 298 feet below land surface is not related to depth. The four highest specific capacities, in descending order, are at depths of 174-198, 90-92, 118-119, and 34-37 feet below land surface.
\end{abstract}

\section{INTRODUCTION}

The AIW Frank/Mid County Mustang Superfund Site is in West Whiteland Township, Chester County, Pa., on U.S. Route 30 (fig. 1). The 15-acre site consists of two adjoining properties. The AIW Frank Property is at 717 East Lincoln Highway (Route 30) and the Mid-County Mustang property (currently Rex Carle Automotive) is at 891 East Lincoln Highway (Halliburton NUS, 1991).

The AIW Frank Corporation occupied a small facility used to manufacture styrofoam products and commercial refrigeration units. The site is no longer active. The AIW Frank Corporation first leased the property in 1962 and purchased the property in 1975. AIW Frank operated the facility as a styrofoam products manufacturing plant from 1962 until declaring bankruptcy in 1981. AIW Frank reportedly used trichloroethylene (TCE) and 1,1,1-trichloroethane (TCA) to clean equipment. After bankruptcy, the site was bought and operated by Continental Refrigerator Corporation (CRC). From 1983 to about 1988, CRC manufactured refrigerators, freezers, and warming cabinets for the food-service industry. The front building (no longer existing) was used for manufacturing by AIW Frank and as an office by CRC. The rear building was used for warehousing by AIW Frank and for manufacturing by CRC. Solvents may have been used by CRC to clean metal components of the refrigeration units (Halliburton NUS, 1991).

The U.S. Environmental Protection Agency (USEPA) requested the U.S. Geological Survey (USGS) provide technical assistance to the hydrological investigation being conducted at the AIW Frank/Mid-County Mustang Superfund Site. The USGS conducted borehole geophysical logging, aquifer tests, and aquifer-isolation tests as part of that investigation. 


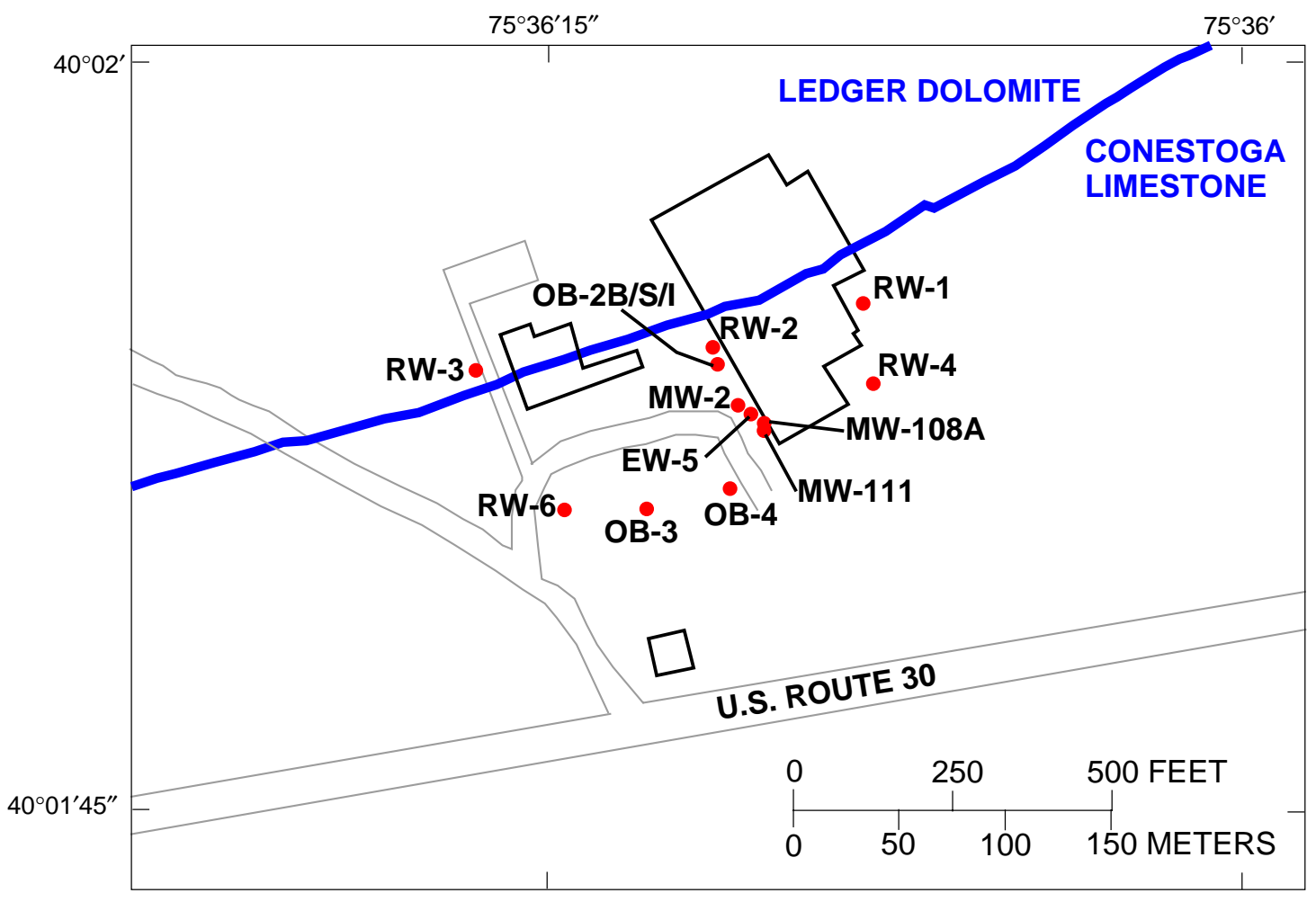

Geology from Bascom and Stose (1938, plate 1)
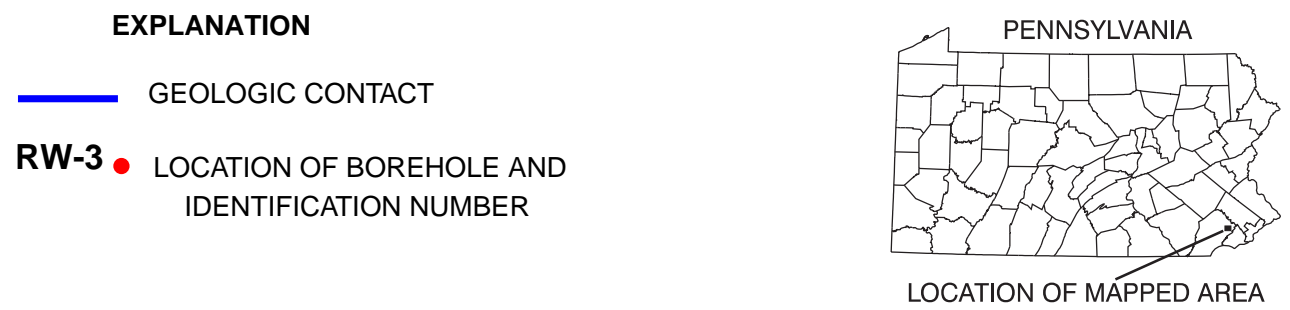

Figure 1. Location of the boreholes where geophysical logging and aquifer-isolation tests were conducted, AIW Frank/Mid-County Mustang Superfund Site, Chester County, Pennsylvania.

\section{Purpose and Scope}

This report provides an interpretation of borehole geophysical logs and heatpulse-flowmeter measurements for six boreholes and provides drawdowns and specific capacities for isolated fracture zones in four boreholes. The USGS collected the data presented here between May 1999 and May 2000 and prepared this report as part of the environmental hydrogeological investigations conducted at the AIW Frank/Mid County Mustang Superfund Site in cooperation with the USEPA. A cross-reference between USGS borehole-identification numbers and site borehole-identification numbers are given in table 1 .

\section{Hydrogeological Setting and Physiography}

The AIW Frank/Mid-County Mustang Superfund Site is in the Piedmont Physiographic Province and is underlain by the Ordovician-age Conestoga Limestone and Cambrian-age Ledger Dolomite (fig. 1). The Ledger Dolomite is a white to light gray, massive to thick-bedded, granular, rather pure dolomite with a high magnesium content. The dolomite is interbedded with some siliceous beds and laminated limestone. The Ledger contains a few beds of marble with a high calcium content (Sloto, 1994). The map of Bascom and Stose (1938, plate 1) shows that the Ledger strikes N. $74^{\circ} \mathrm{E}$. with a near vertical dip to the west of the site and strikes N. $68^{\circ}$ E. with a dip of $60^{\circ}$ to the southeast 
Table 1. Boreholes logged at the AIW Frank/Mid-County Mustang Superfund Site, Chester County, Pennsylvania [--, no data; L, logged depth]

\begin{tabular}{|c|c|c|c|c|c|c|}
\hline $\begin{array}{l}\text { U.S. Geological } \\
\text { Survey borehole- } \\
\text { identification number }\end{array}$ & $\begin{array}{l}\text { Site borehole- } \\
\text { identification } \\
\text { number }\end{array}$ & $\begin{array}{l}\text { Length of casing } \\
\text { below land surface } \\
\text { (feet) }\end{array}$ & $\begin{array}{l}\text { Casing } \\
\text { diameter } \\
\text { (inches) }\end{array}$ & $\begin{array}{l}\text { Depth logged } \\
\text { or drilled } \\
\text { (feet below } \\
\text { land surface) }\end{array}$ & $\begin{array}{c}\text { Depth to } \\
\text { water } \\
\text { (feet below } \\
\text { land surface) }\end{array}$ & $\begin{array}{c}\text { Date } \\
\text { measured }\end{array}$ \\
\hline $\mathrm{CH}-5040$ & EW-5 & 63 & 9 & $298 \mathrm{~L}$ & 23.56 & $6-30-1999$ \\
\hline CH-5804 & RW-1 & 40 & 8.5 & $297 \mathrm{~L}$ & -- & -- \\
\hline CH-5805 & RW-2 & 30 & 8.5 & $184 \mathrm{~L}$ & 21.40 & $3-14-2000$ \\
\hline CH-5806 & RW-3 & 72 & 8.5 & $197 \mathrm{~L}$ & 23.83 & $5-9-2000$ \\
\hline CH-5807 & RW-4 & 18 & 8.5 & $298 \mathrm{~L}$ & -- & -- \\
\hline CH-5808 & RW-6 & 67 & 8.5 & $248 \mathrm{~L}$ & 11.45 & $5-1-2000$ \\
\hline CH-5981 & OB2-S & -- & 2 & 58 & 25.85 & 6-29-1999 \\
\hline CH-5982 & OB2-I & -- & 2 & 86 & 25.72 & 6-29-1999 \\
\hline $\mathrm{CH}-5983$ & OB-3 & -- & -- & -- & 8.47 & $5-1-2000$ \\
\hline $\mathrm{CH}-5984$ & OB-4 & -- & -- & -- & 10.79 & $5-1-2000$ \\
\hline CH-5447 & OB-5 & 21.5 & 6 & $38 \mathrm{~L}$ & -- & -- \\
\hline CH-5985 & MW-2 & 23 & 2 & 44 & 22.27 & 6-29-1999 \\
\hline $\mathrm{CH}-4160$ & MW-108A & 64 & 6.5 & $192 \mathrm{~L}$ & 22.62 & 6-29-1999 \\
\hline CH-5670 & MW-111 & 72 & 2 & 116 & 22.16 & 6-29-1999 \\
\hline
\end{tabular}

to the east of the site. In previous work at the site, Conger and others (2000) used borehole television surveys to measure bedding planes at the site striking east-west and dipping $76^{\circ} \mathrm{S}$. The Ledger is 660 to $1,000 \mathrm{ft}$ thick.

The Conestoga Limestone is a blue-gray, thin-bedded, argillaceous limestone with intervals of a purer, granular limestone. Mica coats most of the bedding and cleavage planes. The impure part of the Conestoga has thin-bedded alterations of dark gray, clayey, silty, slaty, micaceous layers and medium gray, argillaceous limestone that imparts a characteristic banded appearance to the rock. Some of the basal beds are a coarse limestone conglomerate containing large pebbles and irregular masses of coarse white marble in a gray limestone (Sloto, 1994). The map of Bascom and Stose (1938, plate 1) shows that the Conestoga strikes N. $74^{\circ} \mathrm{E}$. with a dip of $85^{\circ}$ to the southeast to the southeast of the site.The Conestoga Limestone is 500 to $800 \mathrm{ft}$ thick (Sloto, 1994). The Ledger and Conestoga are in fault contact.

Ground water in carbonate rocks flows through a network of secondary openings enlarged by solution. Some fractures enlarged by solution are several feet wide; however, most are only a fraction of an inch wide, but they may be capable of transmitting large quantities of water. Solution is the primary weathering process in carbonate rock. Permeability is predominately the result of solution-enlarged fractures. Where solution has been active, permeability may be high; elsewhere, the same unit may be nearly impermeable. Solution generally is most active above and within the zone of water-table fluctuation where water movement is relatively rapid and recharge water is acidic. Below the zone of water-table fluctuation, water movement is slower, and acidic water from recharge is neutralized. Clay and other unconsolidated material sometimes move downward from the surface, plugging openings. This plugging results in decreased well yields and turbid ground-water discharge from some wells. The depth of weathering in carbonate rocks is highly variable. Deeply weathered zones can be found adjacent to outcrops. The carbonate rocks in Chester County commonly exhibit pinnacle weathering. Pinnacle weathering is caused by solution along bedding planes and fractures in dipping strata. As solution enlargement moves downward in the formation, the solid rock between the weathered areas is left as pinnacles (Sloto, 1994).

\section{Acknowledgments}

Borehole geophysical logging was done by Randall Conger, Kim Moyer, and Philip Bird of the Pennsylvania District. Kevin Grazul, Abdul Mohammad, and Leif Olson of the USGS Pennsylvania District and Robert Rosman, Nicholas Smith, and Timothy Oden of the USGS New Jersey District performed the aquifer-isolation (packer) tests. Their assistance is greatly appreciated. 


\section{METHODS OF INVESTIGATION}

\section{Borehole Geophysical Methods}

Caliper, natural-gamma, single-point-resistance, fluid-resistivity, and fluid-temperature logs were collected in six wells. An acoustic borehole televiewer and borehole deviation log were collected in well RW-2. The logs were used to locate water-bearing fractures, determine probable zones of vertical borehole-fluid movement, and determine the depth to set packers.

Caliper logs provide a continuous record of average borehole diameter, which is related to fractures, lithology, and drilling technique. Caliper logs were used to identify fractures and possible water-bearing openings. Correlation of caliper logs with fluid-resistivity and fluid-temperature logs was used to identify water-producing and water-receiving fractures or zones.

Natural-gamma logs, also called gamma-ray logs, record the natural-gamma radiation emitted from rocks penetrated by the borehole. Gamma radiation can be measured through casing, but the gamma response is dampened. Uranium-238, thorium-232, and the progeny of their decay series and potassium- 40 are the most common emitters of natural-gamma radiation.

Single-point-resistance logs record the electrical resistance between the borehole and an electrical ground at land surface. In general, resistance increases with grain size and decreases with borehole diameter, density of water-bearing fractures, and increasing dissolved-solids concentration of borehole fluid (Keys, 1990). A fluid-filled borehole is required for single-point-resistance logs, and they are collected only for the saturated part of the formation below the casing. Single-point-resistance logs sometimes help to identify the location of water-bearing zones because a fluid-filled fracture is less resistive than solid rock.

Fluid-temperature logs provide a continuous record of the temperature of the fluid in the borehole. Fluid-temperature logs were used to identify water-producing and water-receiving zones and to determine intervals of vertical borehole flow. Water-producing and water-receiving zones usually were identified by sharp changes in fluid temperature, and intervals of vertical borehole flow were identified by little or no temperature gradient.

Fluid-resistivity logs measure the electrical resistance of fluid in the borehole. Resistivity is the reciprocal of fluid conductivity, and fluid-resistivity logs reflect changes in the dissolved-solids concentration of the borehole fluid. Fluid-resistivity logs were used to identify water-producing and water-receiving zones and to determine intervals of vertical borehole flow. Water-producing and water-receiving zones usually were identified by sharp changes in fluid resistivity.

The acoustic borehole televiewer log is a magnetically oriented, $360^{\circ}$, photograph-like image of the acoustic reflectivity of the borehole wall. The acoustic televiewer is an ultrasonic imaging tool operating at a frequency of about 1 megahertz that scans the borehole wall with an acoustic beam generated by a rapidly pulsed piezoelectric source rotating at about three revolutions per second as the tool is moved up the borehole. Digital images from the televiewer are recorded by the computer collecting logging data. A smooth and hard borehole wall produces a uniform pattern of reflectivity. The intersection of a fracture with the borehole wall scatters the acoustic waves, producing a dark, linear feature on the image. Because the image is magnetically oriented, the azimuth of the fracture can be determined. Azimuth is the direction of maximum dip of a fracture from 0 to 360 degrees; an azimuth of $90^{\circ}$ would mean a fracture is dipping to the east.

Borehole deviation logs, also called dipmeter logs, record the deviation of a borehole from true vertical. Deviation of boreholes from the vertical is common, and deviation logs are used to calculate true vertical depth of features of interest and to correct the strike and dip of fractures or bedding obtained from acoustic televiewer logs.

\section{Measurement of Vertical Borehole Flow}

The direction and rate of borehole-fluid movement were measured with a high-resolution heatpulse flowmeter. The heatpulse flowmeter operates by diverting nearly all flow to the center of the tool where a heating grid slightly heats a thin zone of water. If vertical borehole flow is occurring, the water moves up or down the borehole to one of two sensitive thermistors (heat sensors). When a peak temperature is recorded by one of the thermistors, a measurement of direction and rate is calculated by the computer collecting the logging data. The range of flow measurement is about 0.01-1.5 gal/min in a 2- to 12-in.-diameter borehole. Heatpulse-flowmeter measurements may be influenced by poor seal integrity between the borehole and the flowmeter or contributions of water from storage within the borehole during pumping. If the seal between the borehole and the heatpulse flowmeter is not complete, some water can bypass the flowmeter, resulting in flow measurements that are less than the actual rate. The quantity of water bypassing the tool is 
a function of borehole size and shape and degree of fracturing. Although the heatpulse flowmeter is a calibrated tool, the data primarily are used as a relative indicator of fluid-producing zones.

Borehole flow was measured under both nonpumping and pumping conditions. Under nonpumping conditions, the natural flow in the borehole is measured. Under pumping conditions, flow is induced in the borehole by pumping, and flow at various depths is measured. To induce flow, a submersible pump is set in the casing, and the well is pumped at a low rate, generally about $1 \mathrm{gal} / \mathrm{min}$. To eliminate the effects of borehole storage, the well is pumped until drawdown stabilizes. After stabilization of drawdown, all of the water being pumped is from the aquifer. A series of measurements under pumping conditions is then made.

\section{Aquifer-Isolation Tests}

Aquifer-isolation tests, commonly known as packer tests, were conducted in four wells. Aquifer-isolation tests use straddle packers to isolate a discrete fracture or fracture zone in the aquifer. Because ground water in the Elbrook Formation and Ledger Dolomite moves through discrete fractures, the hydraulic characteristics and chemical quality of water in each fracture can differ. These differences were characterized by isolating discrete fractures or fracture zones using a straddle-packer assembly to determine depth-discrete specific capacity values, to obtain depth-discrete water samples, and to determine the effect of pumping an isolated fracture or fracture zone on water levels in nearby wells.

The packer assembly consisted of two inflatable rubber bladders (packers) about $4 \mathrm{ft}$ long set on 2-in.-diameter lift pipe with a pump set between the packers. The distance from the center of the upper packer to the center of the lower packer varied from well to well. Packer settings given in this report are from the center of the top packer to the center of the bottom packer, and the isolated zone is considered to be from the center of the top packer to the center of the bottom packer. The lowermost interval generally was tested first; isolated intervals are numbered in order from the bottom to the top of the well.

On the basis of the borehole geophysical logs and heatpulse-flowmeter measurements, several intervals in each well were selected for aquifer-isolation tests. The packer assembly was lowered to the selected depth in the borehole, and the packers were inflated against the borehole wall, isolating the selected interval. Exact depths to set packers were based on the location of smooth sections of borehole wall determined from the caliper logs. For the test of the lowermost isolated interval, generally only the upper packer was inflated (fig. 2A). For the test of the uppermost isolated interval, generally only the lower packer was inflated (fig. 2C). For the test of the other intervals, both packers were inflated (fig. 2B). Inflation of both packers created three intervals - an upper interval above the upper packer, the isolated interval between the packers, and a lower interval below the lower packer. Pressure in the packers was monitored so that the packers always remained at maximum inflation.

In order to evaluate the effects of pumping and fracture interconnection, water levels in the upper, lower, and isolated intervals were measured by calibrated pressure transducers and recorded by a digital data logger. The transducers in the pumped well were set in measurement tubes open to the intervals being monitored. Trandsucers also were set in nearby observation wells. Water levels were initially determined by electric measuring tapes. Land surface datum is used as a reference for all water-level measurements in this report.

Calibrated, in-line flowmeters were used to measure discharge. For some tested intervals, sediment in the discharge water clogged the flowmeter, and periodic volumetric measurements were made to estimate discharge.

After the packers were inflated, water levels in each interval were allowed to stabilize. After water levels stabilized, the aquifer-isolation test was run. During the tests, water levels were recorded above, below, and in the isolated interval. After the pump was shut off, water levels were allowed to recover for approximately 30 minutes before packer deflation to collect recovery water-level data.

The specific capacity of each isolated interval was determined by dividing the time-weighted average pumping rate by the drawdown. Specific capacities in this report should be considered estimates because of the variable pumping rate and because the wells were not pumped long enough to allow for stabilization of drawdown. Specific capacity is affected by the pumping rate and the length of the pumping period. In general, a higher pumping rate and/or a longer pumping duration will result in a lower specific capacity. 


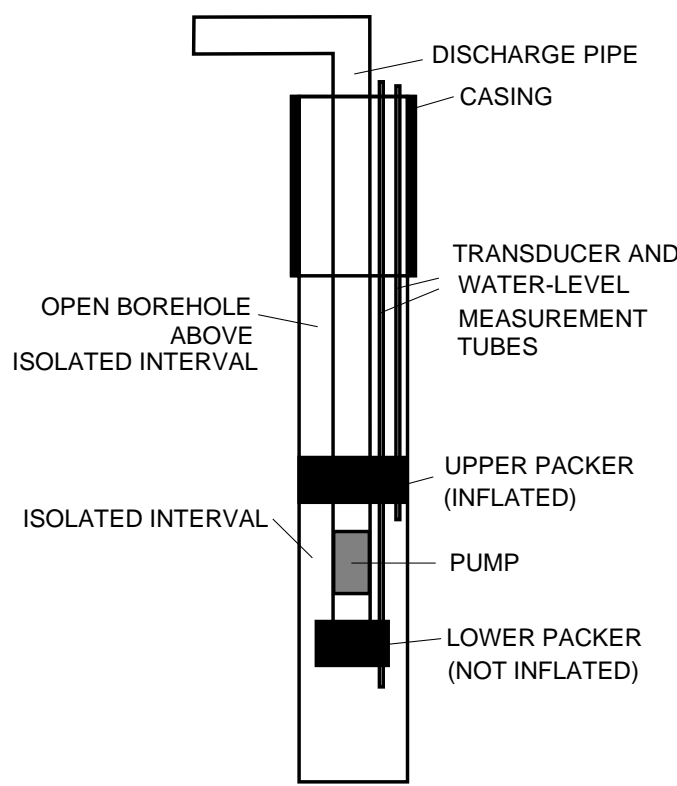

A. UPPER PACKER INFLATED

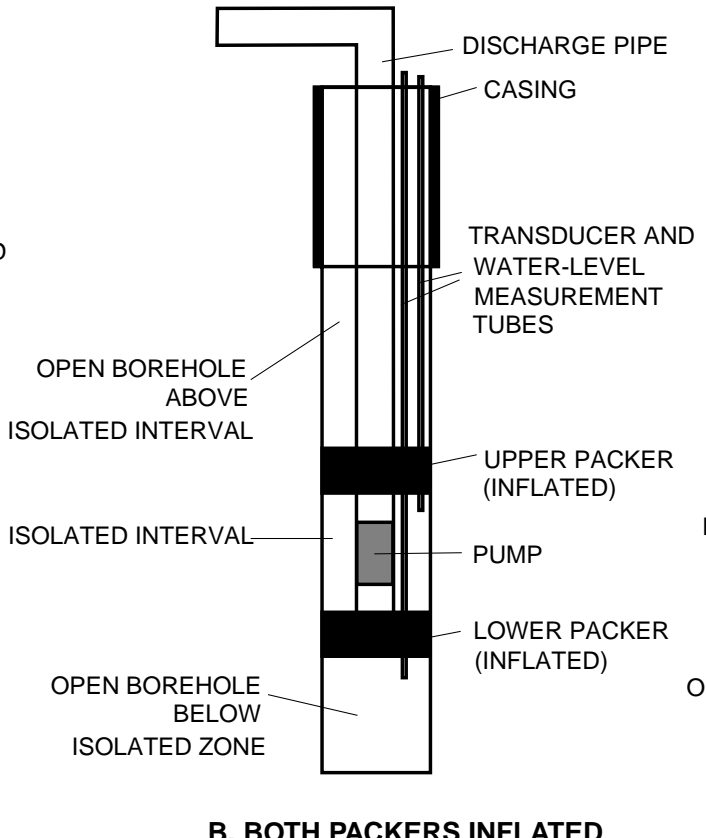

B. BOTH PACKERS INFLATED

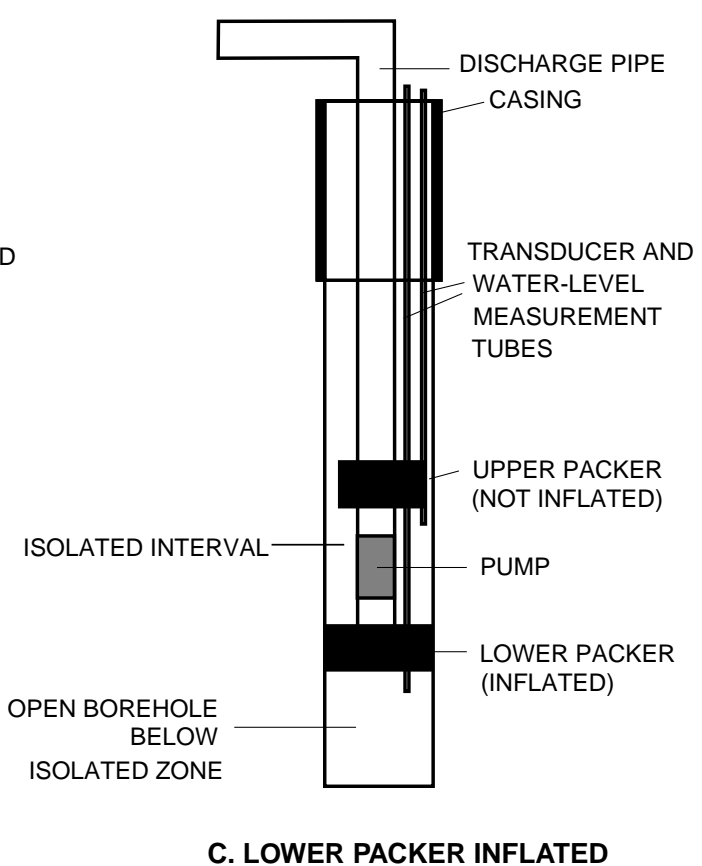

C. LOWER PACKER INFLATED

NOT TO SCALE

Figure 2. Generalized sketch of straddle-packer assembly and pump in borehole. 


\section{EVALUATION OF BOREHOLE GEOPHYSICAL LOGS AND AQUIFER-ISOLATION TESTS}

\section{Well EW-5 (CH-5040)}

\section{Interpretation of Borehole Geophysical Logs}

A suite of borehole geophysical logs (fig. 3) was collected in well EW- 5 by the USGS. The caliper log shows the well is $298 \mathrm{ft}$ deep and is cased to 63 feet below land surface (ft bls). The caliper log shows major fractures at 73, 99, 111, 140-146, 168, and 178-182 ft bls plus numerous smaller fractures. The fracture at $73 \mathrm{ft}$ bls is the major water-producing zone. A secondary water-producing zone is between 260 and $270 \mathrm{ft}$ bls. The fluid-resistivity and fluid-temperature logs do not indicate borehole flow under nonpumping conditions. This was confirmed with heatpulse-flowmeter measurements at $68,80,160,172,196,250$, and $280 \mathrm{ft}$ bls that showed no measurable flow.
Heatpulse-flowmeter measurements were made at $68,80,160,196,250$, and $280 \mathrm{ft}$ bls while the well was pumped at approximately $0.35 \mathrm{gal} / \mathrm{min}$ with a submersible pump set in the casing. Under pumping conditions, the heatpulse-flowmeter measurements showed the fracture at $73 \mathrm{ft}$ bls produces about $0.3 \mathrm{gal} / \mathrm{min}$ of water, and the fracture at $260-270 \mathrm{ft}$ bls produced about $0.05 \mathrm{gal} / \mathrm{min}$ of water.

\section{Aquifer-Isolation Tests}

On the basis of the borehole geophysical logs and heatpulse-flowmeter measurements, three intervals were selected for aquifer-isolation tests (table 2). Water levels in nearby wells MW-111, MW-2, and MW-108A were monitored in addition to water levels in EW-5 during pumping to determine the effect of pumping on nearby wells. The distance between the center of the top packer and the center of the bottom packer was $17 \mathrm{ft}$.

Table 2. Intervals isolated and specific capacities for well EW-5 (CH-5040), AIW Frank/Mid-County Mustang Superfund Site, Chester County, Pennsylvania

[--, insufficient data to calculate specific capacity]

\begin{tabular}{cccccc}
\hline Interval & $\begin{array}{c}\text { Isolated interval } \\
\text { (feet below } \\
\text { land surface) }\end{array}$ & $\begin{array}{c}\text { Isolated fracture } \\
\text { (feet below } \\
\text { land surface) }\end{array}$ & $\begin{array}{c}\text { Pumping time } \\
\text { (minutes) }\end{array}$ & $\begin{array}{c}\text { Time-weighted average } \\
\text { pumping rate } \\
\text { (gallons per minute) }\end{array}$ & $\begin{array}{c}\text { Specific capacity } \\
\text { (gallons per minute } \\
\text { per foot) }\end{array}$ \\
\hline 1 & $257-300$ & $260-270$ & 80 & 1.1 & - \\
2 & $194-300$ & $260-270$ & 97 & .98 & 0.005 \\
3 & $63-80$ & 73 & 70 & 3.6 & .08 \\
\hline
\end{tabular}

${ }^{1}$ Center of packer to center of packer. 

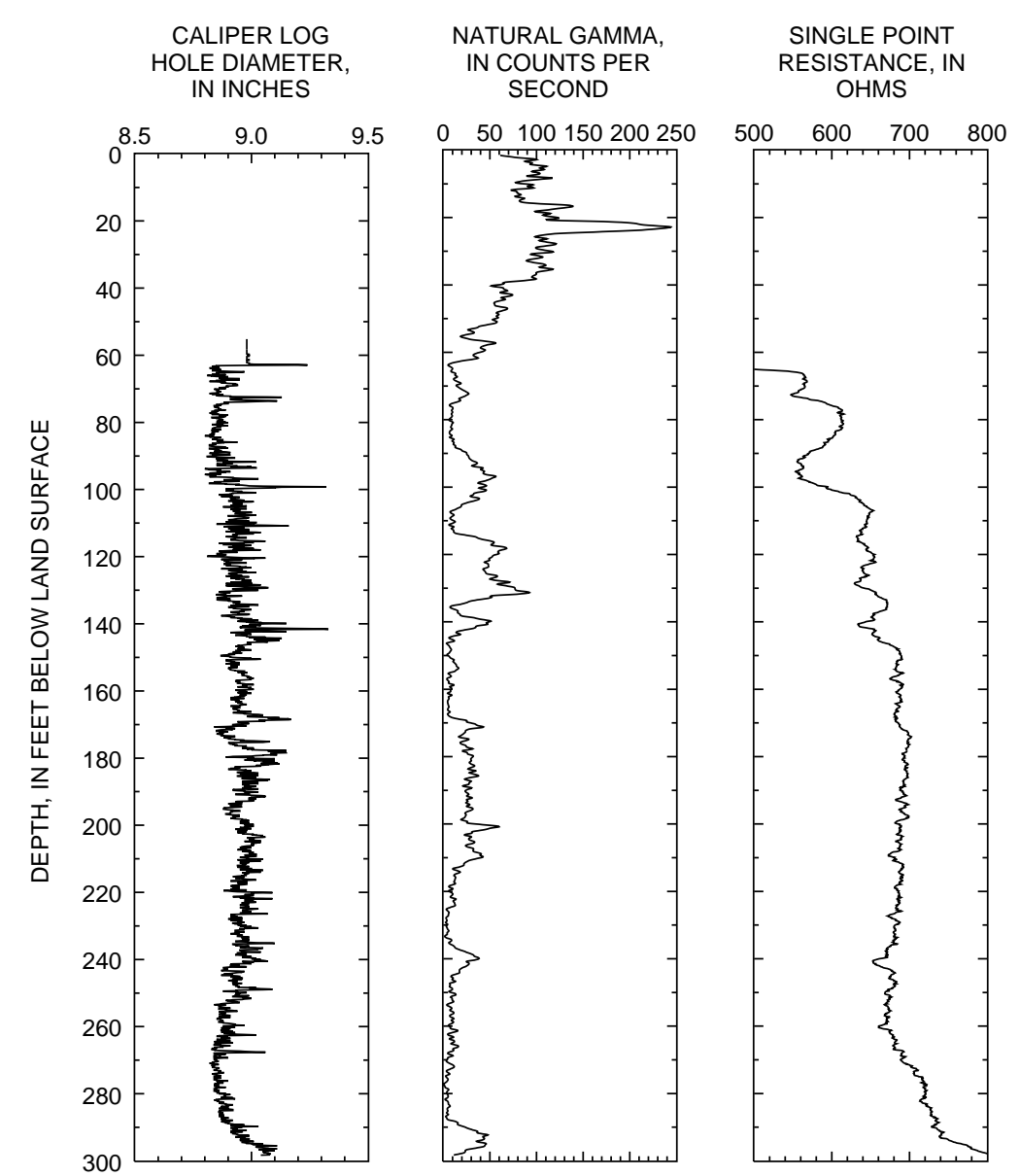

FLUID
TEMPERATURE, IN
DEGREES CELSIUS

FLUID RESISTIVITY

$50-100150200250$

OHMS

IN OHM-METERS
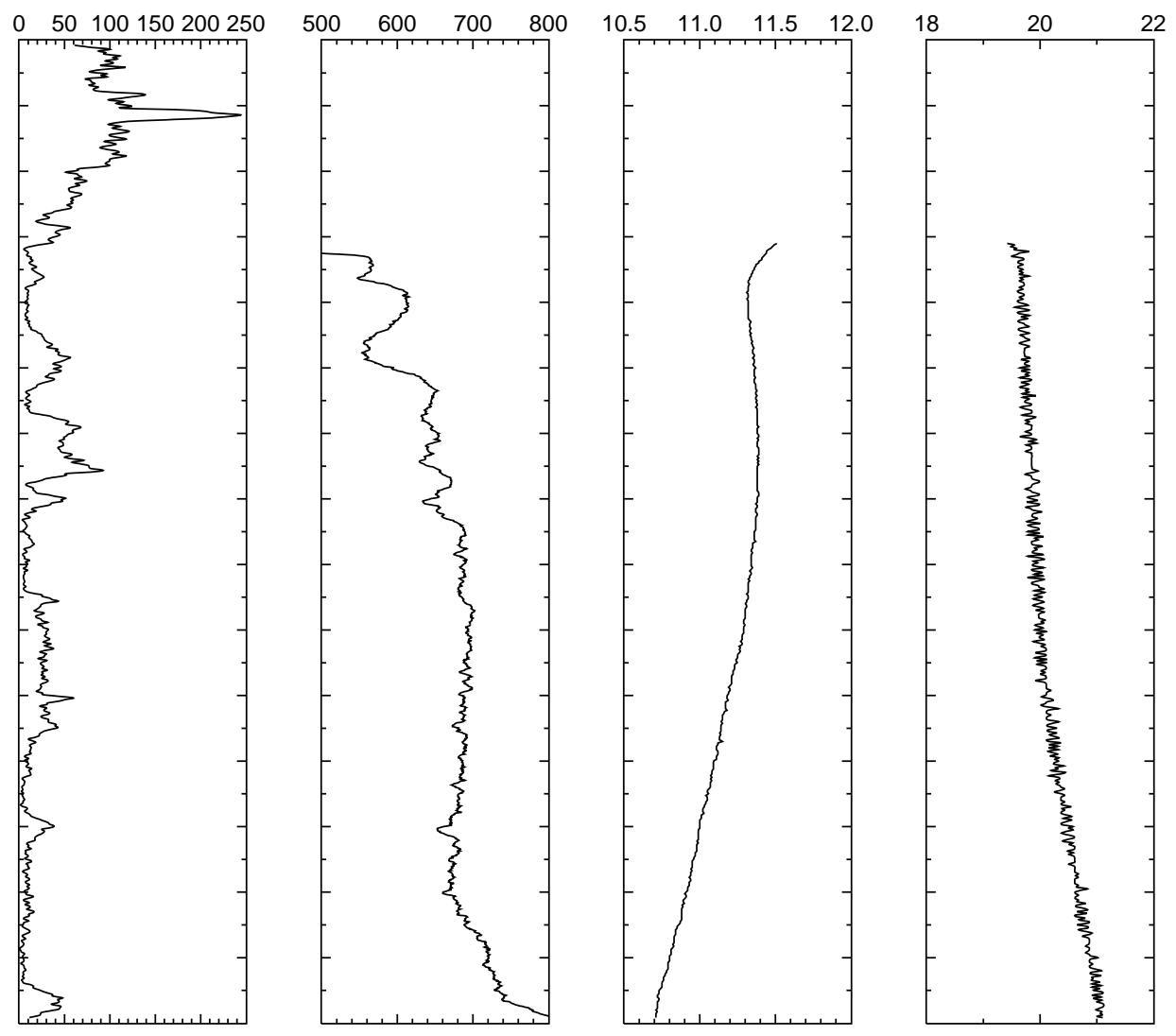

Figure 3. Borehole geophysical logs from well EW-5 (CH-5040), AIW Frank/Mid-County Mustang Superfund Site, Chester County, Pennsylvania. 


\section{Aquifer-Isolation Test of Interval 1 (257 to 298 Feet Below Land Surface)}

For isolated interval 1, the top packer was centered at $257 \mathrm{ft}$ bls, and the bottom packer was not inflated (fig. 2A). The interval of borehole isolated was from 257 to the bottom of the borehole at $298 \mathrm{ft}$ bls. This included the minor water-producing fracture at 260-270 ft bls. The pump was set at $215 \mathrm{ft}$ bls. Isolated interval 1 was pumped four times at rates from 0.5 to $1.5 \mathrm{gal} / \mathrm{min}$ resulting in rapid drawdowns with water levels for the first three times dropping below the transducer, which was set at $129.37 \mathrm{ft}$ bls (fig. 4). The maximum drawdown in the interval above the packer was $1.22 \mathrm{ft}$. The water level in the pumped interval below the packer dropped below the transducer; the maximum drawdown was greater than $105.59 \mathrm{ft}$. The specific capacity of interval 1 could not be calculated because the exact drawdown was not known. The hydrographs for the intervals above and below the packer and for the observation wells are shown in figure 4 . The hydrographs indicate a hydraulic connection outside the borehole between the two intervals. The maximum drawdown in well MW-108A was $0.16 \mathrm{ft}$, indicating a hydraulic connection between the isolated interval and well MW-108A.

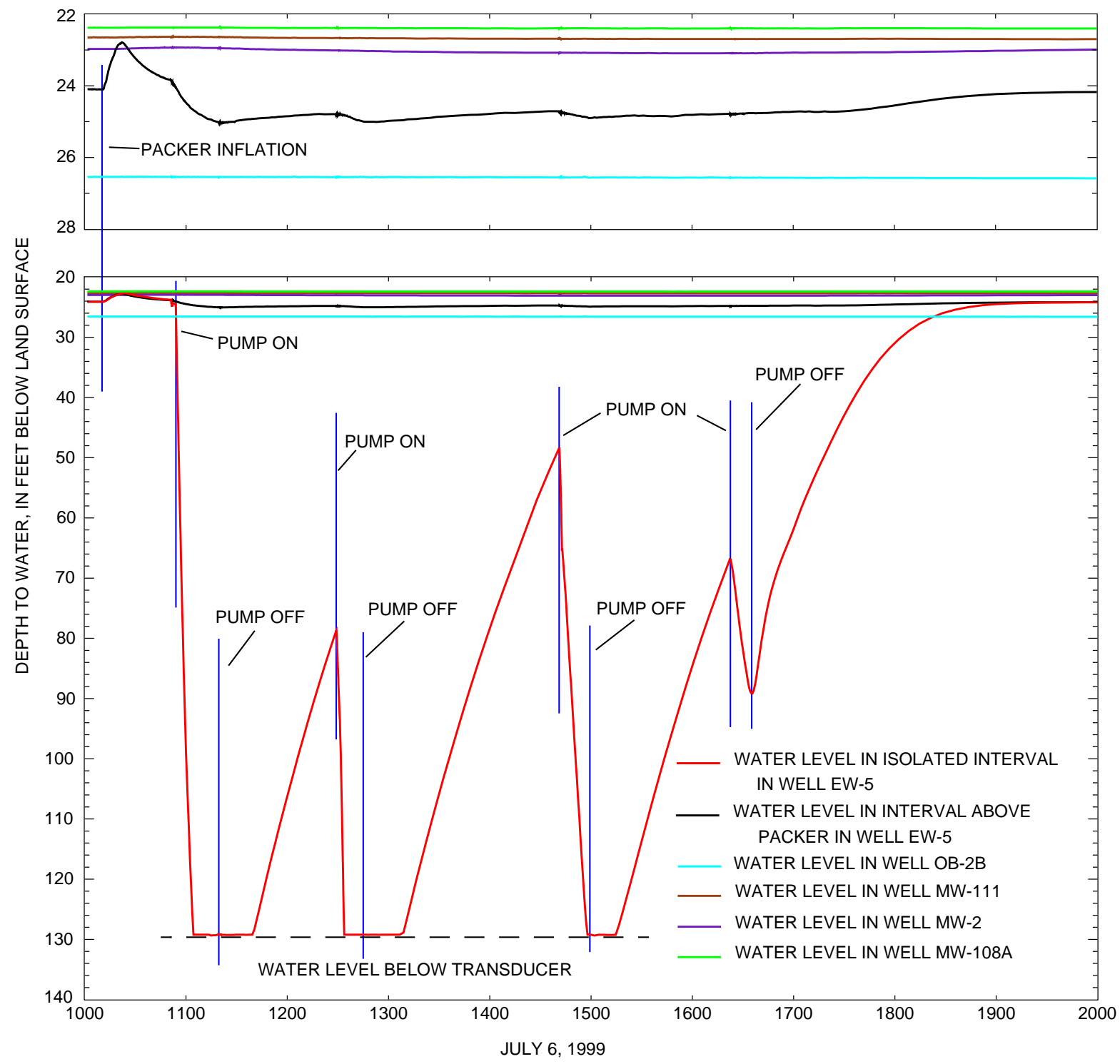

Figure 4. Hydrographs from aquifer-isolation test of interval 1 (257 to 298 feet below land surface) in well EW-5 (CH-5040), AIW Frank/Mid-County Mustang Superfund Site, Chester County, Pennsylvania. 


\section{Aquifer-Isolation Test of Interval 2 (194 to 298 Feet Below Land Surface)}

For isolated interval 2, the top packer was centered at $194 \mathrm{ft}$ bls, and the bottom packer was not inflated (fig. 2A). The interval of borehole isolated was from 194 to $298 \mathrm{ft}$ bls. This isolated the lower part of the well and included the minor water-producing fracture at 260-270 ft bls. Isolated interval 2 was pumped at an average rate of $0.98 \mathrm{gal} / \mathrm{min}$ for 97 minutes, which resulted in the water level dropping below the transducer, which was set at $130.65 \mathrm{ft}$ bls (fig. 5). The water level measured by electric tape just before the pump was shut off was $186 \mathrm{ft}$ bls for a measured drawdown of $163 \mathrm{ft}$. The specific capacity of interval 2 is 0.005 ( $\mathrm{gal} / \mathrm{min}) / \mathrm{ft}$.

Drawdown in the interval above the packer was $5.10 \mathrm{ft}$. The hydrographs for the isolated interval and the interval above the packer and for the observation wells are shown in figure 5 . The hydrographs indicate a hydraulic connection outside the borehole between the two intervals. The maximum drawdown was $0.14 \mathrm{ft}$ in well MW-2 and $0.56 \mathrm{ft}$ in well MW-108A, indicating that the wells are hydraulically connected to isolated interval 2 in well EW-5. Drawdown in well MW-108A continued for 53 minutes after cessation of pumping of well EW-5. Well OB-2B showed no response to pumping.

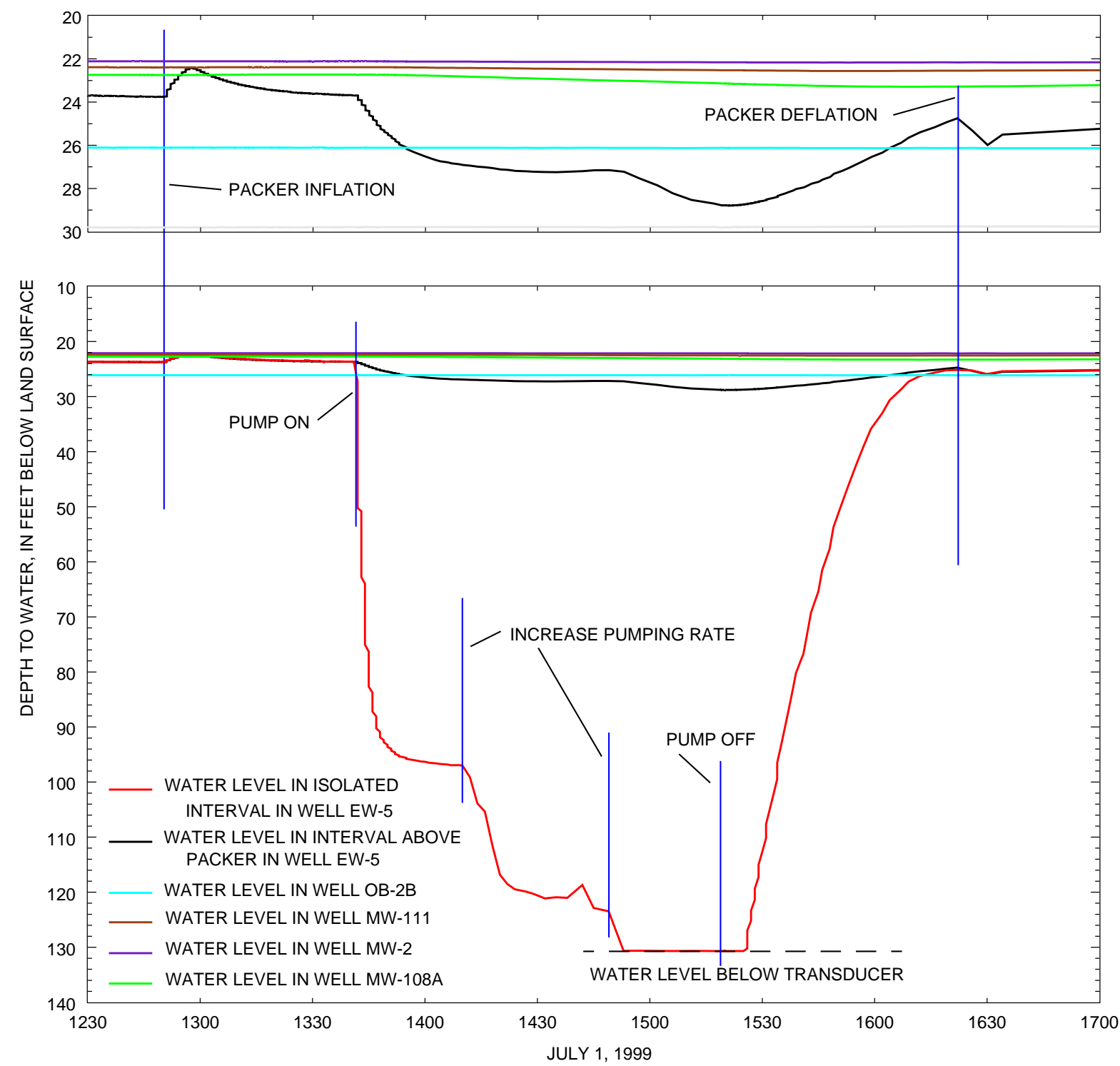

Figure 5. Hydrographs from aquifer-isolation test of interval 2 (194 to 298 feet below land surface) in well EW-5 (CH-5040), AIW Frank/Mid-County Mustang Superfund Site, Chester County, Pennsylvania. 


\section{Aquifer-Isolation Test of Interval 3 (63 to 80 Feet Below Land Surface)}

For isolated interval 3, the bottom packer was centered at $84 \mathrm{bls}$, and the top packer was not inflated (fig. 2C); this isolated the main water-bearing fracture at $73 \mathrm{ft}$ bls. Isolated interval 3 was pumped at an average rate of $3.6 \mathrm{gal} / \mathrm{min}$ for 70 minutes. The maximum drawdown measured in the isolated interval was $42.71 \mathrm{ft}$ (fig. 6). The specific capacity of interval 3 is $0.08(\mathrm{gal} / \mathrm{min}) / \mathrm{ft}$.
Drawdown in the interval above the packer was $39.41 \mathrm{ft}$, indicating a very strong hydraulic connection outside the borehole between the two intervals. The hydrographs for the isolated interval and the interval above the packer and for the observation wells are shown in figure 6 . The maximum drawdown was 0.10 , 0.35 , and $1.44 \mathrm{ft}$ in wells MW-111, MW-2, and MW-108A, respectively, indicating the wells are hydraulically connected to the isolated interval in well EW-5. Drawdown in well MW-108A continued for 75 minutes after cessation of pumping of well EW-5. Well OB-2B showed no response to pumping.

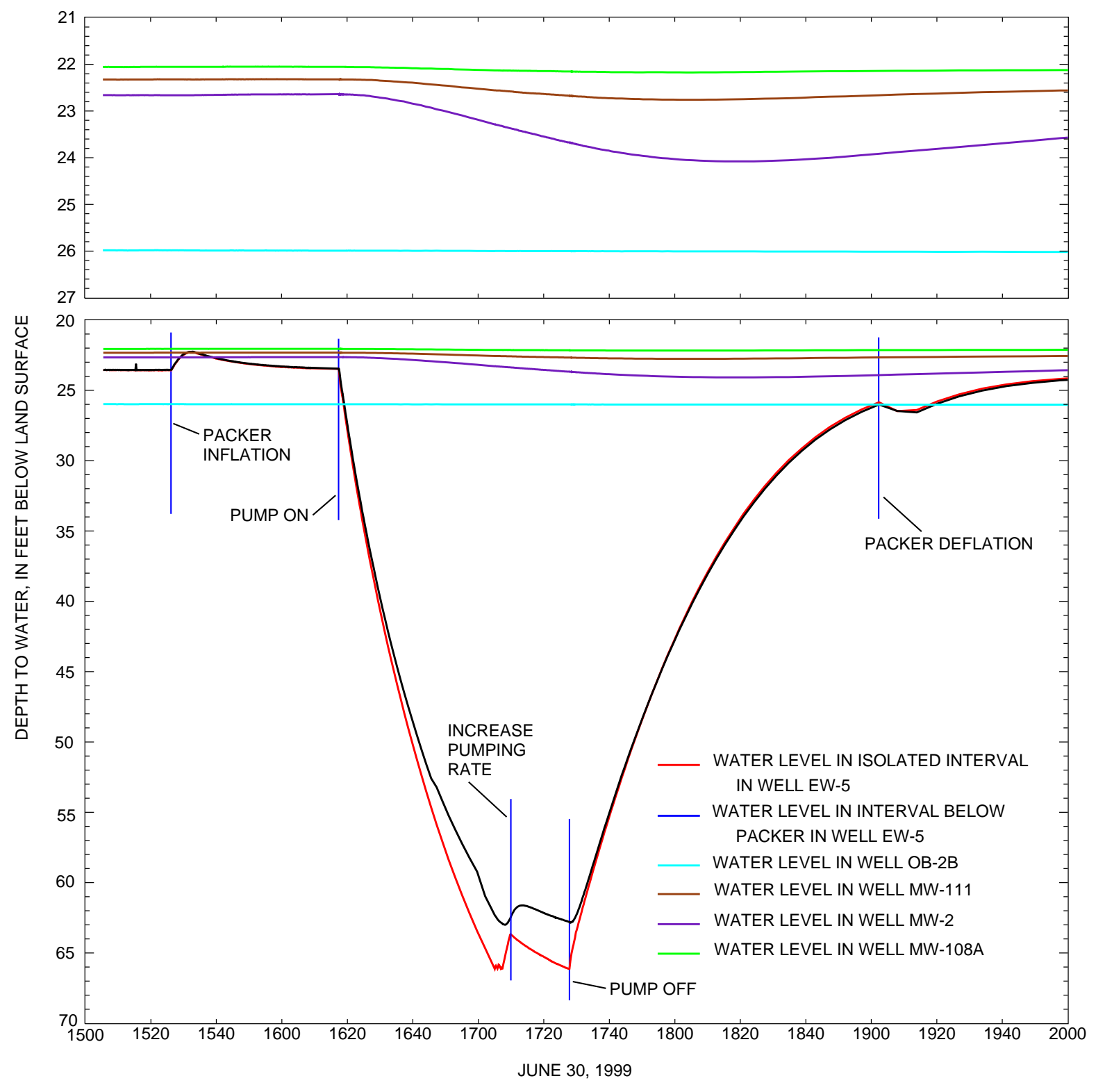

Figure 6. Hydrographs from aquifer-isolation test of interval 3 (63 to 80 feet below land surface) in well EW-5 (CH-5040), AIW Frank/Mid-County Mustang Superfund Site, Chester County, Pennsylvania. 


\section{Well RW-2 (CH-5805)}

\section{Interpretation of Borehole Geophysical Logs}

A suite of borehole geophysical logs (fig. 7) was collected in well RW-2 by the USGS. The caliper log shows the bottom of the well is filled with sediment to about $184 \mathrm{ft}$ bls, and it is cased to $30 \mathrm{ft}$ bls. The caliper $\log$ shows major fractures at 34-36, 37, 68-72, and $97-98 \mathrm{ft}$ bls. A minor fracture is located at $168-170 \mathrm{ft}$ bls. An acoustic borehole televiewer log was run in the well. Dip and azimuth for the water-bearing fractures are given in table 3 . The water-bearing fractures are very steeply dipping; the dip ranges from $72^{\circ}$ to $78.8^{\circ}$. This is consistent with dips measured by Bascom and Stose (1938, plate 1). Heatpulse-flowmeter measurements were made under nonpumping conditions at 47 , $62,86,104,120,140,158,162$, and $174 \mathrm{ft}$ bls (table 4). On the basis of the geophysical logs, heatpulse-flowmeter measurements, and acoustic borehole televiewer data, water enters the borehole through fractures at 34-36 and $37 \mathrm{ft}$ bls and flows downward. Water also enters the borehole through the minor fracture at

Table 3. Fracture dip and azimuth determined with the acoustic borehole televiewer for water-bearing fractures in well RW-2 (CH-5805), AlW Frank/Mid-County Mustang Superfund Site, Chester County, Pennsylvania

\begin{tabular}{ccc}
\hline $\begin{array}{c}\text { Depth of fracture } \\
\text { (feet below land surface) }\end{array}$ & $\begin{array}{c}\text { Dip } \\
\text { (degrees) }\end{array}$ & $\begin{array}{c}\text { Azimuth } \\
\text { (degrees) }\end{array}$ \\
\hline 36.8 & 78.8 & 162.4 \\
55.7 & 76.9 & 166.5 \\
70.2 & 74.5 & 165.0 \\
98.7 & 74.7 & 163.6 \\
170.1 & 72.0 & 149.6 \\
\hline
\end{tabular}

168-170 ft bls and flows upward. Water flowing down the borehole from the fractures at $34-36$ and $37 \mathrm{ft}$ bls exits the borehole through fractures at 55, 68-72, and 97-98 ft bls. Water flowing up the borehole from the fracture at $168-170 \mathrm{ft}$ bls exits the borehole through the fracture at $97-98 \mathrm{ft}$ bls. The principal water-bearing zones in well RW-2 are at 34-37, 55, 68-72, 97-98, and $168-170 \mathrm{ft}$ bls.

\section{Aquifer-Isolation Tests}

On the basis of the borehole geophysical logs and heatpulse-flowmeter measurements, five intervals were selected for isolation by straddle packers (table 5). The distance between the center of the top packer and the center of the bottom packer was $15 \mathrm{ft}$. During pumping, water levels in nearby observation wells OB2-S, EW-5, OB2-I, MW-108A, and MW-2 were monitored in addition to water levels in RW-2.

Table 4. Heatpulse-flowmeter measurements made in well RW-2 (CH-5805), AIW Frank/Mid-County Mustang Superfund Site, Chester County, Pennsylvania

$[--$, not determined]

\begin{tabular}{ccc}
\hline $\begin{array}{c}\text { Depth } \\
\text { (feet below } \\
\text { land surface) }\end{array}$ & $\begin{array}{c}\text { Flow } \\
\text { (gallons } \\
\text { per minute) }\end{array}$ & $\begin{array}{c}\text { Flow } \\
\text { direction }\end{array}$ \\
\hline 47 & 0.69 & Down \\
62 & .62 & Down \\
86 & .43 & Down \\
104 & .20 & $\mathrm{Up}$ \\
120 & .20 & $\mathrm{Up}$ \\
140 & .20 & $\mathrm{Up}$ \\
158 & .20 & $\mathrm{Up}$ \\
162 & Inconsistent & -- \\
174 & Inconsistent & -- \\
\hline
\end{tabular}

Table 5. Intervals isolated and specific capacities for well RW-2 (CH-5805), AIW Frank/Mid-County Mustang Superfund Site, Chester County, Pennsylvania

[--, specific capacity not determined]

\begin{tabular}{|c|c|c|c|c|c|}
\hline $\begin{array}{l}\text { Interval } \\
\text { number }\end{array}$ & $\begin{array}{c}\text { Isolated interval }^{1} \\
\text { (feet below land surface) }\end{array}$ & $\begin{array}{c}\text { Isolated fracture } \\
\text { (feet below land surface) }\end{array}$ & $\begin{array}{l}\text { Pumping time } \\
\text { (minutes) }\end{array}$ & $\begin{array}{l}\text { Average pumping rate } \\
\text { (gallons per minute) }\end{array}$ & $\begin{array}{c}\text { Specific capacity } \\
\text { (gallons per minute } \\
\text { per foot) }\end{array}$ \\
\hline 1 & $160-184$ & $168-170$ & 114 & 3.9 & -- \\
\hline 2 & $90-105$ & $97-98$ & 94 & 25 & 1.3 \\
\hline 3 & $61-76$ & $68-72$ & 97 & 3.9 & .14 \\
\hline 4 & $45-60$ & 55 & 30 & 1.8 & -- \\
\hline 5 & $30-45$ & $34-37$ & 91 & 19.9 & 1.6 \\
\hline
\end{tabular}

\footnotetext{
${ }^{1}$ Center of packer to center of packer.
} 
NATURAL GAMMA, SINGLE POINT

FLUID

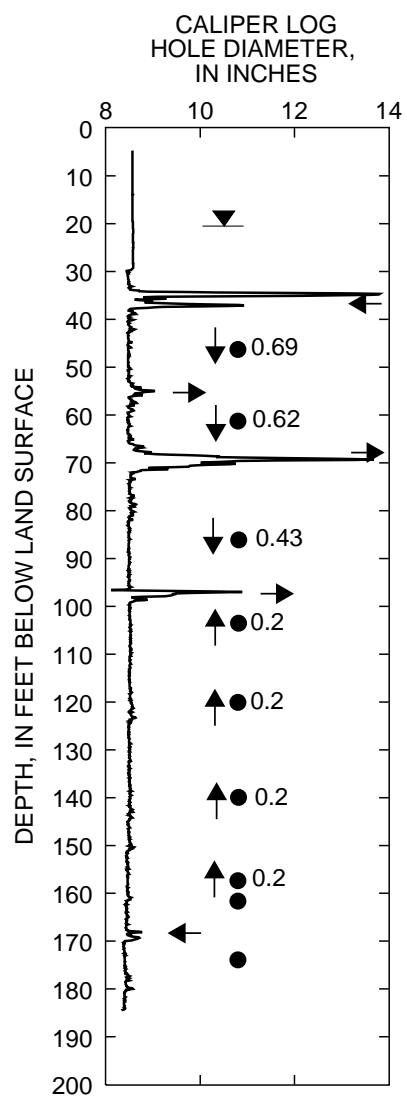
SECOND
SONTS
S

RINGLE POINT
OHMS

$0 \quad 50 \quad 100 \quad 150$

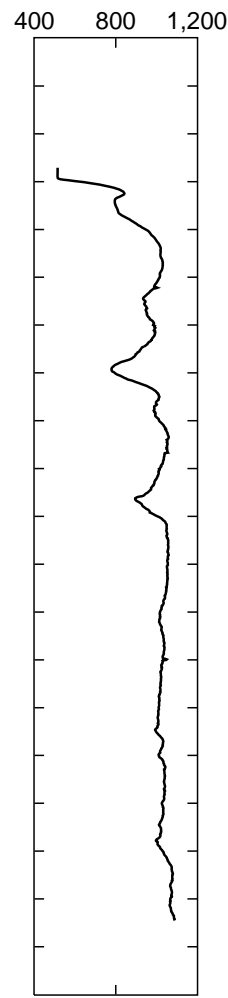
DEGREES CELSIUS

FLUID RESISTIVITY,
IN OHM-METERS
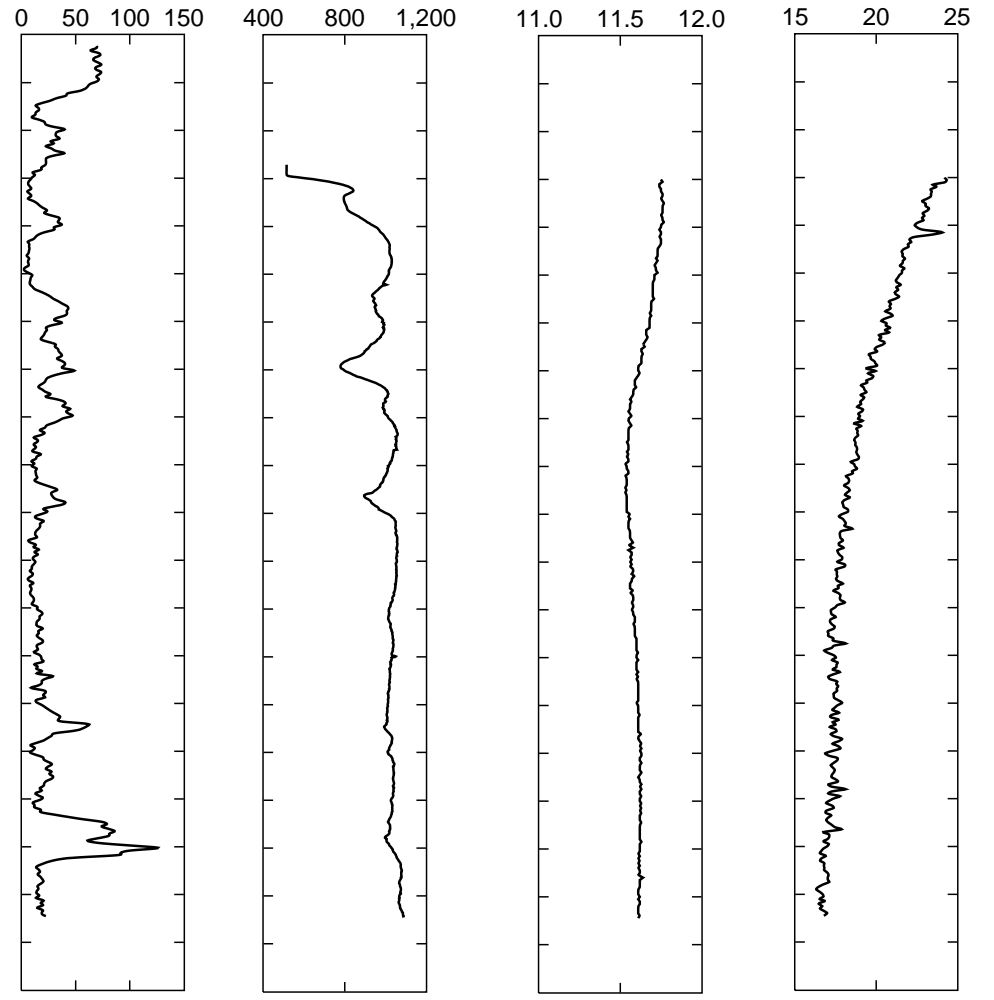

\section{EXPLANATION}

$\checkmark$ WATER LEVEL-Measured in well at the time of geophysical logging

- 0.2 BOREHOLE-FLOW MEASUREMENT UNDER NONPUMPING CONDITIONSCircle at depth of flow measurement. per minute

4 DIRECTION OF VERTICAL BOREHOLE FLOWUpward arrow indicates upward flow; downward arrow indicates downward flow

$\longleftarrow$ FLOW INTO BOREHOLEArrow pointing toward caliper log indicates flow into borehole

$\rightarrow$ FLOW OUT OF BOREHOLEArrow pointing away from caliper log
indicates flow out of borehole

Figure 7. Borehole geophysical logs from well RW-2 (CH-5805), AIW Frank/Mid-County Mustang Superfund Site, Chester County, Pennsylvania 


\section{Aquifer-Isolation Test of Interval 1 (160 to 184 Feet Below Land Surface)}

For isolated interval 1, the top packer was centered at $160 \mathrm{ft}$ bls, and the bottom packer was not inflated (fig. 2A). The interval of borehole isolated was from $160 \mathrm{ft}$ bls to the bottom of the well at $184 \mathrm{ft}$ bls. This interval includes the water-producing fracture at $168-170 \mathrm{ft}$ bls. Before packer inflation, the depth to water in the open borehole was $21.40 \mathrm{ft}$ bls. Fifty minutes after packer inflation, the depth to water in the isolated interval increased by $0.03 \mathrm{ft}$., while the depth to water in the interval above the isolated zone decreased by $0.14 \mathrm{ft}$. This is consistent with the interpretation of the borehole geophysical logs and upward borehole flow shown by the heatpulse-flowmeter measurements, which indicate the isolated water-producing fracture at 168$170 \mathrm{ft}$ bls has a higher head than the water-receiving fractures above. Inflation of the packers had no effect on the water levels in the observation wells.

Isolated interval 1 is a relatively low-yielding zone; it was pumped at an average rate of $3.9 \mathrm{gal} / \mathrm{min}$ for 114 minutes (fig. 8). The pumping rate varied during the test. Drawdown in the interval above the packer was $1.66 \mathrm{ft}$. The water level in the isolated interval dropped below the transducer, which was set at $133 \mathrm{ft}$ bls; the maximum drawdown was greater than $111 \mathrm{ft}$. The specific capacity of interval 1 could not be calculated because the drawdown was not known.

The hydrographs for well RW-2 and the observation wells are shown in figure 8 . The hydrographs indicate a hydraulic connection outside the borehole between the isolated interval and the interval above the packer and with well OB-2S. Drawdown in well OB-2S caused by pumping the interval isolated from 160 to $184 \mathrm{ft}$ bls in well RW-2 was $1.43 \mathrm{ft}$.

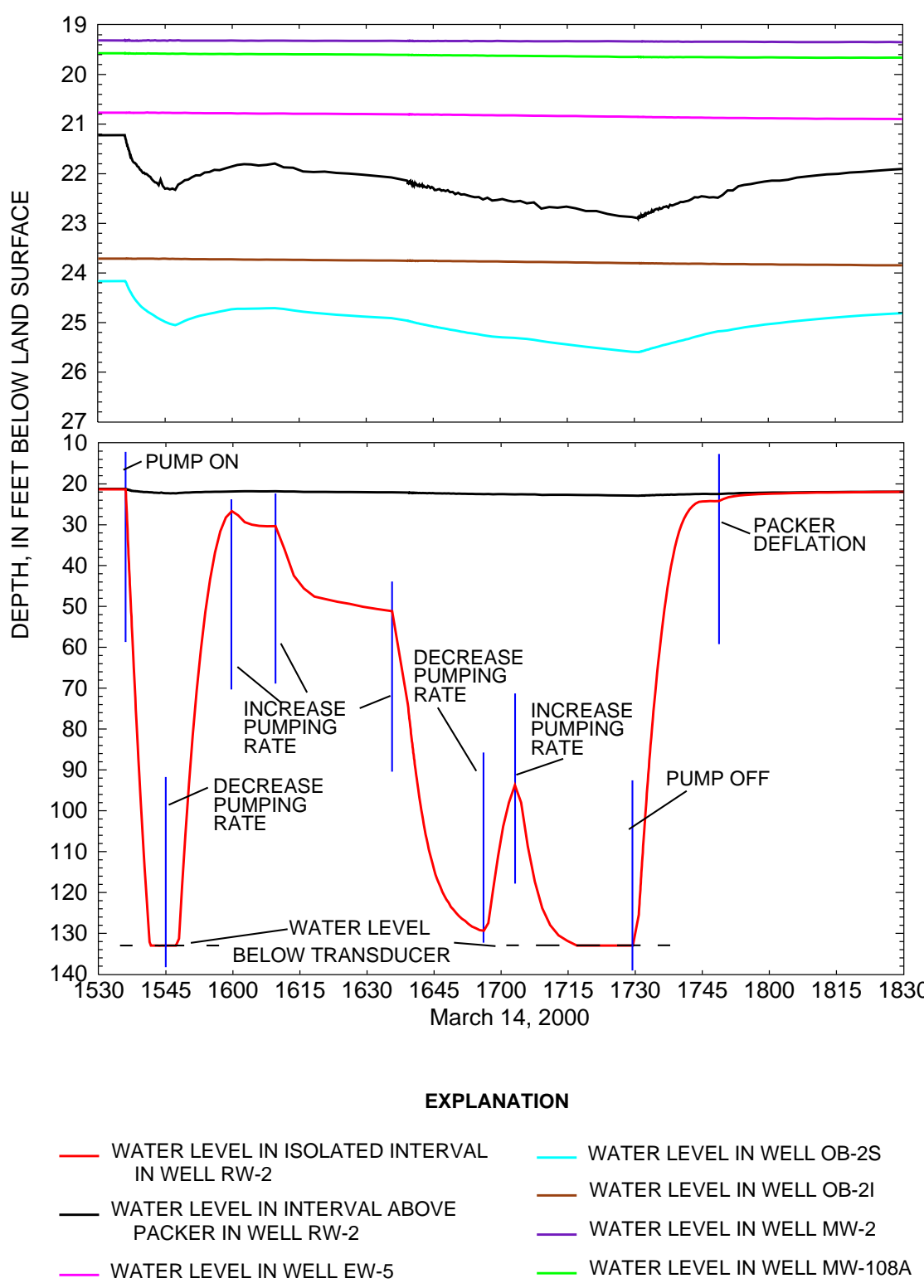

Figure 8. Hydrographs from aquifer-isolation test of interval 1 (160 to 184 feet below land surface) in well RW-2 (CH-5805), AIW Frank/Mid-County Mustang Superfund Site, Chester County, Pennsylvania. 

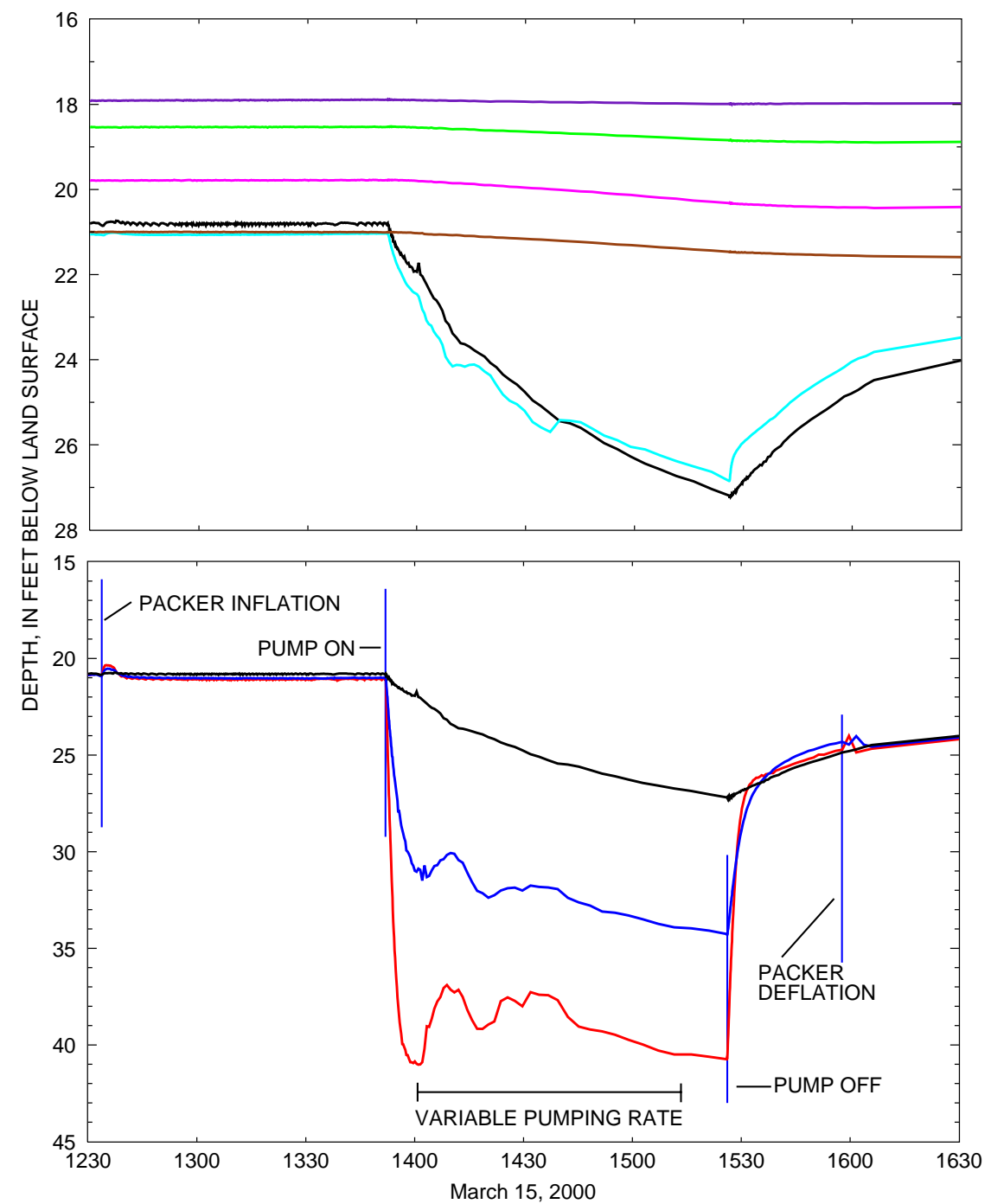

EXPLANATION

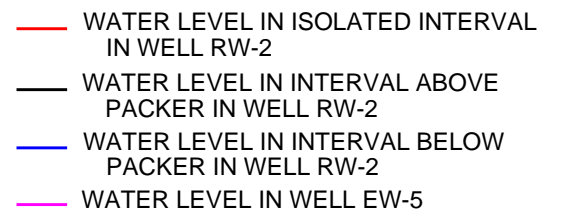

Figure 9. Hydrographs from aquifer-isolation test of interval 2 (90 to 105 feet below land surface) in well RW-2 (CH-5805), AIW Frank/Mid-County Mustang Superfund Site, Chester County, Pennsylvania.
Aquifer-Isolation Test of Interval 2 (90 to 105 Feet Below Land Surface)

For isolated interval 2, the top packer was centered at $90 \mathrm{ft}$ bls (fig. 2B), and the interval of borehole isolated was from 90 to $105 \mathrm{ft}$ bls. This interval includes the major water-receiving fracture at 97-98 ft bls. Before packer inflation, the depth to water in the open borehole was $20.94 \mathrm{ft}$ bls. Eighty-six minutes after packer inflation, depth to water in the interval above the packers increased $0.12 \mathrm{ft}$, depth to water in the isolated interval decreased $0.12 \mathrm{ft}$, and depth to water in the interval below the packers decreased $0.05 \mathrm{ft}$. This is consistent with the interpretation of the borehole geophysical logs, which indicate the isolated water-receiving fracture at $97-98 \mathrm{ft}$ bls has a lower head than the water-producing fractures above and below. Inflating the packers caused a rise in water level of $0.45 \mathrm{ft}$ in well OB-2S.

Isolated interval 2 is a relatively high-yielding zone; it was pumped at an average rate of $25 \mathrm{gal} / \mathrm{min}$ for 94 minutes. Drawdown in the interval above the packers was $6.46 \mathrm{ft}$, drawdown in the isolated interval was $19.63 \mathrm{ft}$, and drawdown in the interval below the packers was $13.31 \mathrm{ft}$ (fig. 9). The specific capacity of interval 2 is $1.3(\mathrm{gal} / \mathrm{min}) / \mathrm{ft}$. The hydrographs for wells RW-2 and the observation wells are shown in figure 9. The hydrographs indicate a strong hydraulic connection outside the borehole between the isolated interval and the intervals above and below the isolated interval. Drawdown in well OB-2S caused by pumping the isolated interval was $5.82 \mathrm{ft}$, indicating a strong hydraulic connection between the isolated interval 90-105 ft bls in well RW-2 and well OB-2S. 


\section{Aquifer-Isolation Test of Interval 3 (61 to 76 Feet Below Land Surface)}

For isolated interval 3, the top packer was centered at $61 \mathrm{ft}$ bls (fig. 2B), and the interval of borehole isolated was from $61-76 \mathrm{ft}$ bls. This interval includes the water-receiving fracture at $67-72 \mathrm{ft}$ bls. Before packer inflation, the depth to water in the open borehole was $20.94 \mathrm{ft}$ bls. Fifty-five minutes after packer inflation, depth to water in the interval above the packer increased $0.04 \mathrm{ft}$, depth to water in the isolated interval decreased $0.18 \mathrm{ft}$, and depth to water in the interval below the packer decreased $0.23 \mathrm{ft}$. This is consistent with the interpretation of the borehole geophysical logs, which indicate the isolated water-receiving fracture at 67-72 ft bls has a lower head than the water-producing fractures above it. Inflating the packers caused a rise in water level of $0.12 \mathrm{ft}$ in well OB-2S.

Isolated interval 3 is a relatively low-yielding zone; it was pumped at a time-weighted average rate of $3.9 \mathrm{gal} / \mathrm{min}$ for 97 minutes (fig. 10). Drawdown in the interval above the packers was $1.08 \mathrm{ft}$, drawdown in the isolated interval was $27.14 \mathrm{ft}$, and drawdown in the interval below the packers was $0.67 \mathrm{ft}$. The specific capacity of interval 3 is

0.14 (gal/ $/ \mathrm{min}) / \mathrm{ft}$. The hydrographs for the intervals above and below the packer and for well OB-2S are shown in figure 10 . The hydrographs indicate a strong hydraulic connection outside the borehole between the isolated interval and the intervals above and below the isolated interval. Drawdown in well OB-2S caused by pumping the isolated interval was $1.04 \mathrm{ft}$, indicating a strong hydraulic connection between the isolated interval 61-76 ft bls in well RW-2 and well OB-2S.

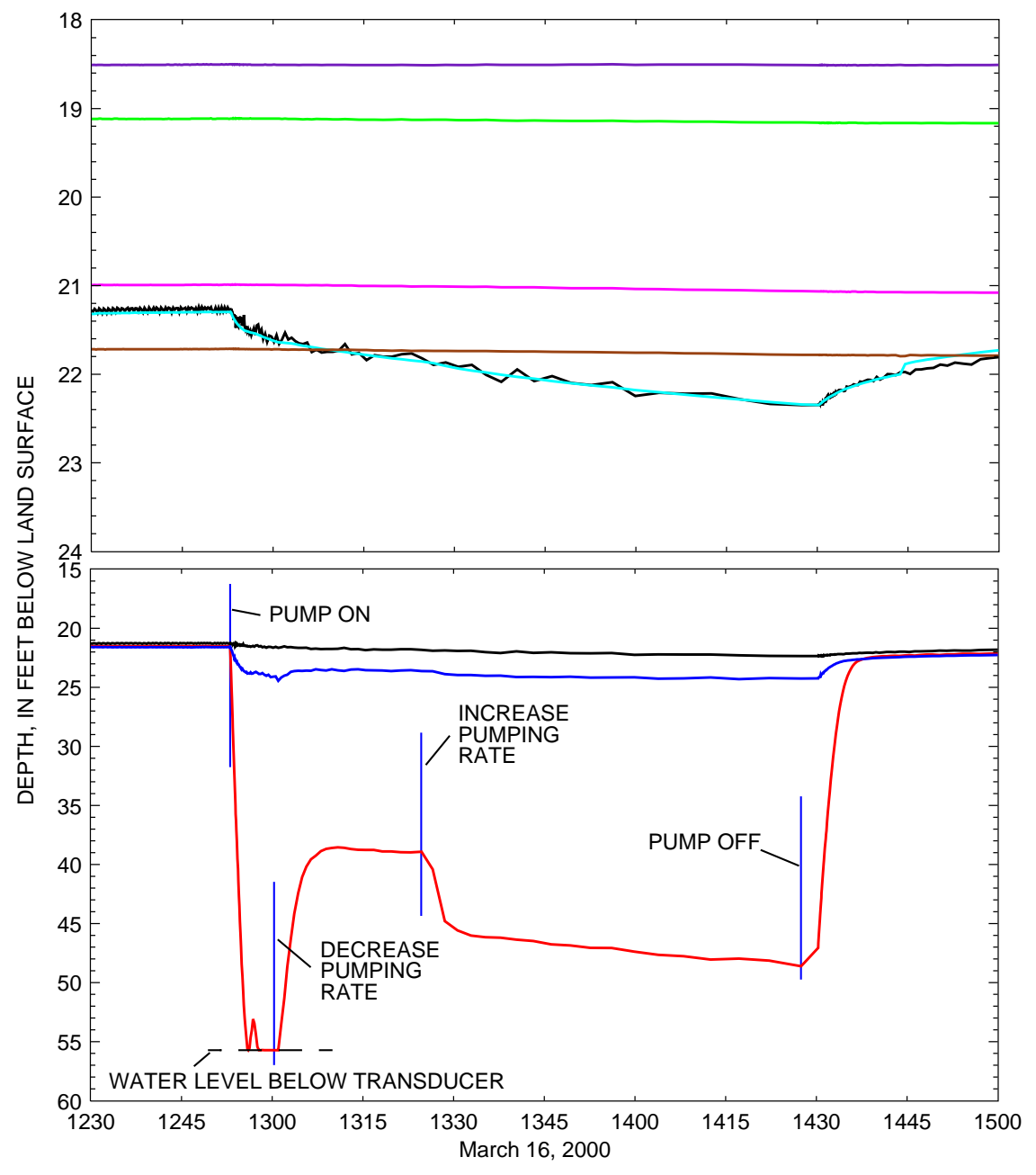

EXPLANATION

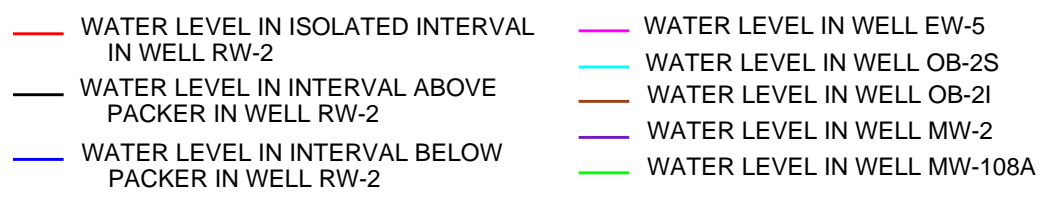

Figure 10. Hydrographs from aquifer-isolation test of interval 3 (61 to 76 feet below land surface) in well RW-2 (CH-5805), AIW Frank/Mid-County Mustang Superfund Site, Chester County, Pennsylvania. 


\section{Aquifer-Isolation Test of Interval 4 (45 to 60 Feet Below Land Surface)}

For isolated interval 4, the top packer was centered at $45 \mathrm{ft}$ bls (fig. 2B), and the interval of borehole isolated was from $45-60 \mathrm{ft}$ bls. This interval includes the minor water-receiving fracture at $55 \mathrm{ft}$ bls. Before packer inflation, the depth to water in the open borehole was $21.10 \mathrm{ft}$ bls. Fifty-six minutes after packer inflation, depth to water in the interval above the packer increased $0.03 \mathrm{ft}$, depth to water in the isolated interval increased $0.08 \mathrm{ft}$, and depth to water in the interval below the packer decreased $0.10 \mathrm{ft}$. This is consistent with the interpretation of the borehole geophysical logs, which indicate the isolated water-receiving fracture at $55 \mathrm{ft}$ bls has a lower head than the water-producing fracture above it. Inflating the packers caused a rise in water level of $0.13 \mathrm{ft}$ in well OB-2S.
Isolated interval 4 is a very low-yielding zone. It was pumped dry, allowed to recover, and then pumped a second time (fig. 11). The average pumping rate was $1.8 \mathrm{gal} / \mathrm{min}$ for 73 minutes. The maximum drawdown in the interval above the packers was $0.37 \mathrm{ft}$, and the maximum drawdown in the interval below the packers was $0.95 \mathrm{ft}$. The water level in the isolated interval dropped below the transducer, which was set at $39 \mathrm{ft}$ bls. The maximum drawdown was greater than $17 \mathrm{ft}$. The specific capacity of interval 4 could not be calculated because drawdown was not known. The maximum drawdown in well OB-2S caused by pumping the isolated interval was $0.35 \mathrm{ft}$, indicating a hydraulic connection between the isolated interval 45-60 ft bls in well RW-2 and well OB-2S.

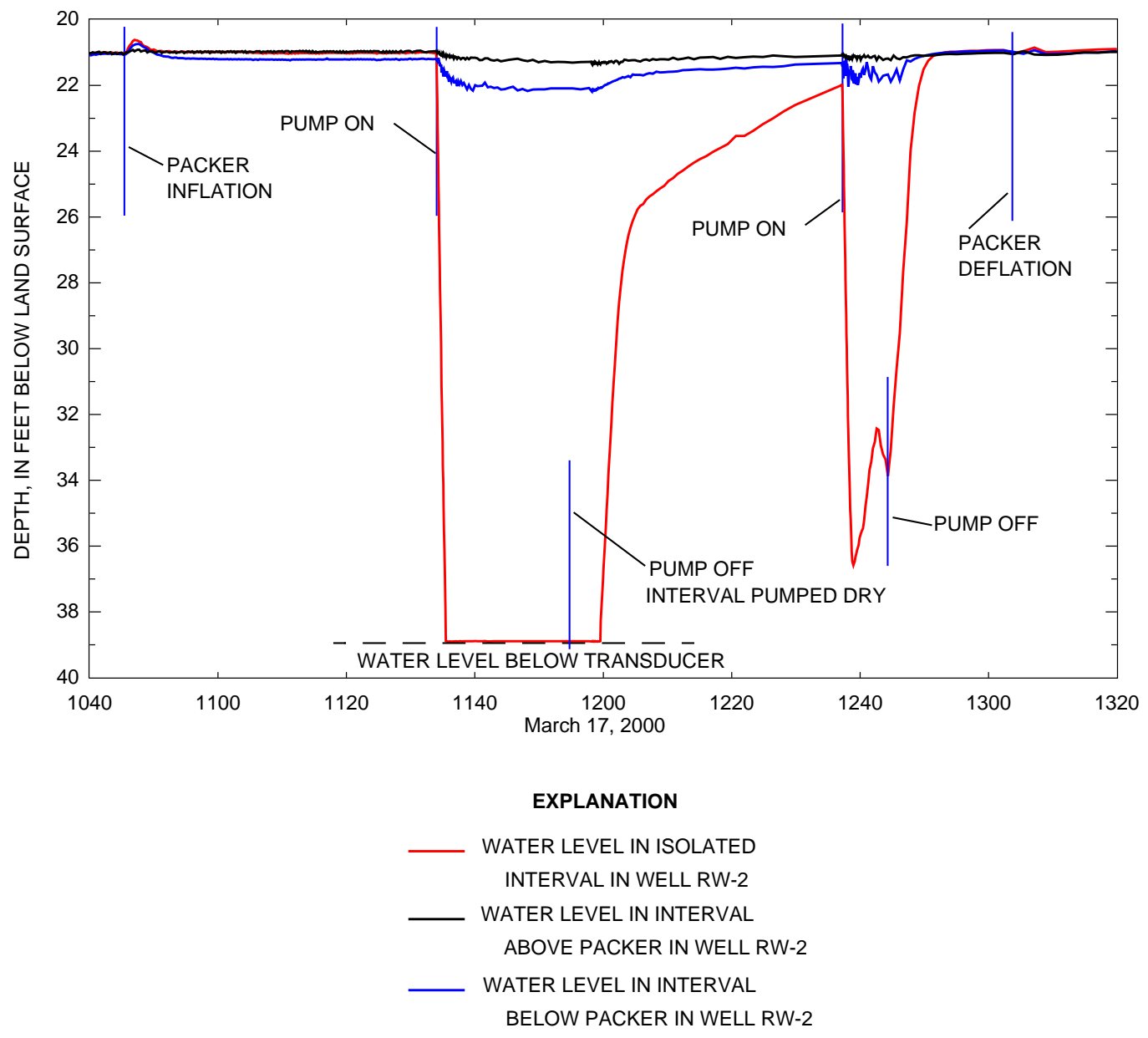

Figure 11. Hydrographs from aquifer-isolation test of interval 4 (45 to 60 feet below land surface) in well RW-2 (CH-5805), AIW Frank/Mid-County Mustang Superfund Site, Chester County, Pennsylvania. 


\section{Aquifer-Isolation Test of Interval 5 (30 to 45 Feet Below Land Surface)}

For isolated interval 5, the bottom packer was centered at $45 \mathrm{ft}$ bls (fig. 2C), and the top packer was not inflated. The interval of borehole isolated was from the bottom of casing at $30 \mathrm{ft}$ bls to $45 \mathrm{ft}$ bls. This interval includes the major water-producing fractures at 34-36 and $37 \mathrm{ft}$ bls. Before packer inflation, the depth to water in the open borehole was $20.95 \mathrm{ft}$ bls.

Twenty-eight minutes after packer inflation, depth to water in the isolated interval above the packer increased $0.07 \mathrm{ft}$, and depth to water in the interval below the packer decreased $0.11 \mathrm{ft}$. This is consistent with the interpretation of the borehole geophysical logs, which indicate the isolated water-producing fractures at 34-36 and $37 \mathrm{ft}$ bls has a higher head than the water-receiving fractures below them. Inflating the packers caused a decrease in water level of $0.06 \mathrm{ft}$ in well OB-2S.
Isolated interval 5 is a relatively high-yielding zone; it was pumped at an average rate of $19.9 \mathrm{gal} / \mathrm{min}$ for 91 minutes. Drawdown in the isolated interval was $12.65 \mathrm{ft}$, and drawdown in the interval below the packers was $3.77 \mathrm{ft}$. The specific capacity of interval 5 is 1.6 (gal/min)/ft. The hydrographs for well RW-2 and the observation wells are shown in figure 12. The hydrographs indicate a strong hydraulic connection outside the borehole between the isolated interval and the interval below the packer. Drawdown in well OB-2S caused by pumping the isolated interval was $8.69 \mathrm{ft}$, indicating a strong hydraulic connection between the isolated interval $30-45 \mathrm{ft}$ bls in well RW-2 and well OB-2S. Drawdowns were observed in all of the other observation wells. Drawdown was $0.33 \mathrm{ft}$ in well EW-5, $0.28 \mathrm{ft}$ in well OB-2I, $0.19 \mathrm{ft}$ in well WM-108A, and $0.07 \mathrm{ft}$ in well MW-2.

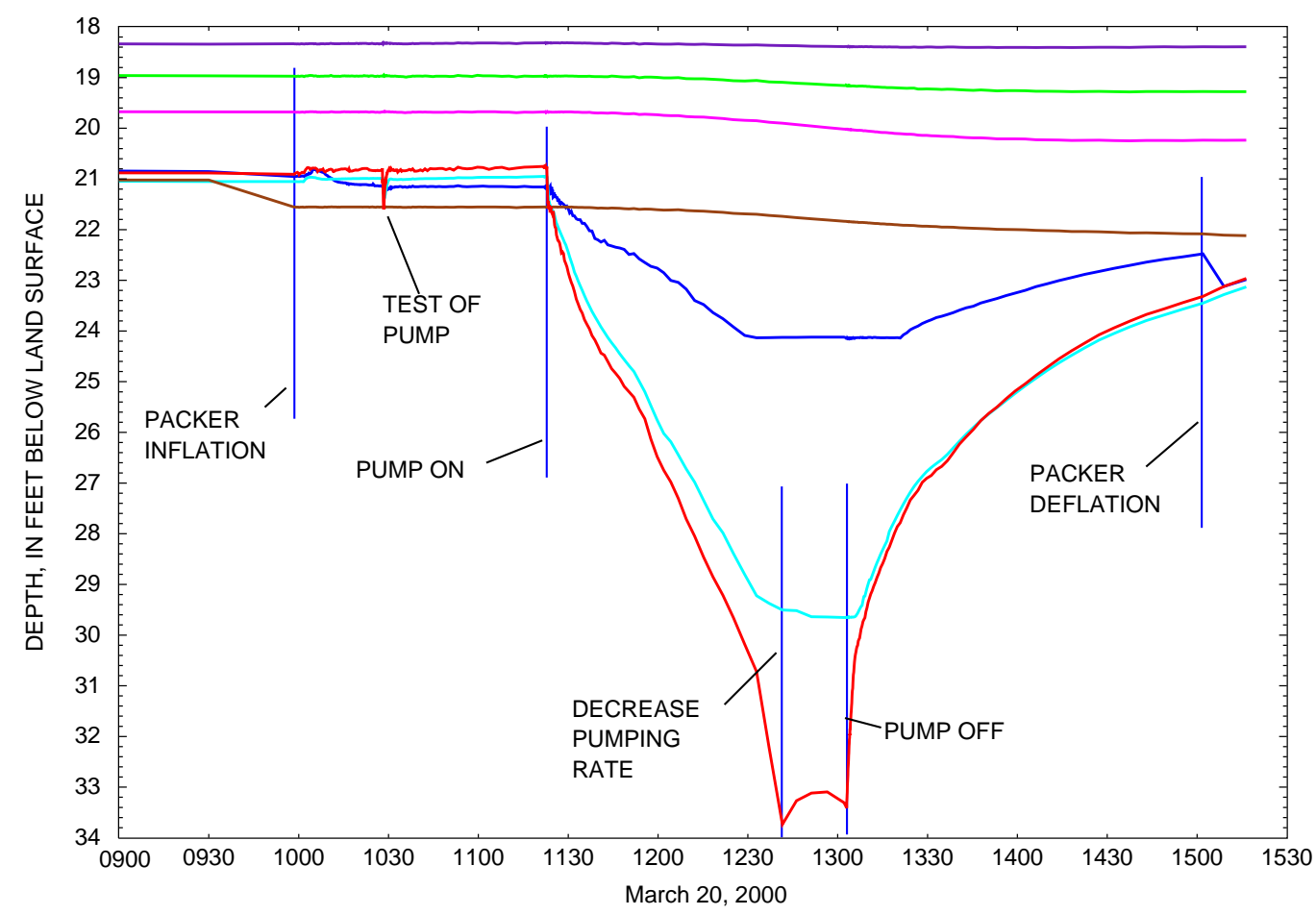

EXPLANATION

WATER LEVEL IN ISOLATED INTERVAL IN WELL RW-2

WATER LEVEL IN INTERVAL BELOW PACKER IN WELL RW-2
WATER LEVEL IN WELL EW-5 WATER LEVEL IN WELL OB-2S WATER LEVEL IN WELL OB-2I WATER LEVEL IN WELL MW-2 WATER LEVEL IN WELL MW-108A

Figure 12. Hydrographs from aquifer-isolation test of interval 5 (30 to 45 feet below land surface) in well RW-2 (CH-5805), AIW Frank/Mid-County Mustang Superfund Site, Chester County, Pennsylvania. 


\section{Well RW-3 (CH-5806)}

\section{Interpretation of Borehole Geophysical Logs}

A suite of borehole geophysical logs (fig. 13) was collected in well RW-3 by the USGS. The caliper log shows the well is $197 \mathrm{ft}$ deep and is cased to $72 \mathrm{ft}$ bls. Major fractures are at 120-124, 154-156, 175-176, and $179 \mathrm{ft}$ bls. Heatpulse-flowmeter measurements were made under nonpumping conditions at 78, 110, 140, 166 , and $184 \mathrm{ft}$ bls (table 6). No borehole flow was measurable at 78, 110, and $140 \mathrm{ft}$ bls. Downward borehole flow of 0.17 and $0.23 \mathrm{gal} / \mathrm{min}$ was measured at 166 and $184 \mathrm{ft}$ bls, respectively. Water enters the borehole through fractures at 154-156 and 174-179 ft bls, flows downward, and exits the borehole through fractures below $194 \mathrm{ft}$ bls. Heatpulse-flowmeter measure- ments were made while pumping at 0.7 to $1 \mathrm{gal} / \mathrm{min}$ at 78, 110, 140, 166, 184, 190, and $194 \mathrm{ft}$ bls (table 6). On the basis of the geophysical logs and heatpulse-flowmeter measurements, the principal water-bearing zones in the well are at 153-156 ft bls, $174-279 \mathrm{ft}$ bls, and below $194 \mathrm{ft}$ bls.

\section{Aquifer-Isolation Tests}

On the basis of the borehole geophysical logs and heatpulse-flowmeter measurements, three intervals were isolated in well RW-3 (table 7). The distance between the center of the top packer and the center of the bottom packer was $19 \mathrm{ft}$. No observation wells were measured during the aquifer-isolation test of well RW-3.

Table 6. Heatpulse-flowmeter measurements made in well RW-3 (CH-5806), AIW Frank/Mid-County Mustang Superfund Site, Chester County, Pennsylvania

[--, not measured]

\begin{tabular}{|c|c|c|c|c|}
\hline \multirow{2}{*}{$\begin{array}{c}\text { Depth } \\
\text { (feet below land surface) }\end{array}$} & \multicolumn{2}{|c|}{ Nonpumping conditions } & \multicolumn{2}{|c|}{ Pumping at 0.7 to 1 gallon per minute } \\
\hline & $\begin{array}{c}\text { Flow } \\
\text { (gallons per minute) }\end{array}$ & $\begin{array}{c}\text { Flow } \\
\text { direction }\end{array}$ & $\begin{array}{c}\text { Flow } \\
\text { (gallons per minute) }\end{array}$ & $\begin{array}{c}\text { Flow } \\
\text { direction }\end{array}$ \\
\hline 78 & 0 & & 0.62 & $\mathrm{Up}$ \\
\hline 110 & 0 & & .80 & Up \\
\hline 140 & 0 & & .67 & $\mathrm{Up}$ \\
\hline 166 & .17 & Down & .83 & Up \\
\hline 184 & .23 & Down & .71 & Up \\
\hline 190 & -- & -- & .49 & Up \\
\hline 194 & -- & -- & .60 & Up \\
\hline
\end{tabular}

Table 7. Intervals isolated and specific capacities for well RW-3 (CH-5806), AIW Frank/Mid-County Mustang Superfund Site, Chester County, Pennsylvania

\begin{tabular}{|c|c|c|c|c|c|}
\hline $\begin{array}{l}\text { Interval } \\
\text { number }\end{array}$ & $\begin{array}{c}\text { Isolated interval }^{1} \\
\text { (feet below land surface) }\end{array}$ & $\begin{array}{c}\text { Isolated fracture } \\
\text { (feet below land surface) }\end{array}$ & $\begin{array}{l}\text { Pumping time } \\
\text { (minutes) }\end{array}$ & $\begin{array}{l}\text { Average pumping rate } \\
\text { (gallons per minute) }\end{array}$ & $\begin{array}{c}\text { Specific capacity } \\
\text { (gallons per minute } \\
\text { per foot) }\end{array}$ \\
\hline 1 & $164-198$ & $\begin{array}{l}174-179 \\
194-198\end{array}$ & 107 & ${ }^{2} 25$ & 7.1 \\
\hline 2 & $148-167$ & $153-156$ & 73 & 2.34 & .006 \\
\hline 3 & $109-128$ & $122-126$ & 94 & 4.1 & .07 \\
\hline
\end{tabular}



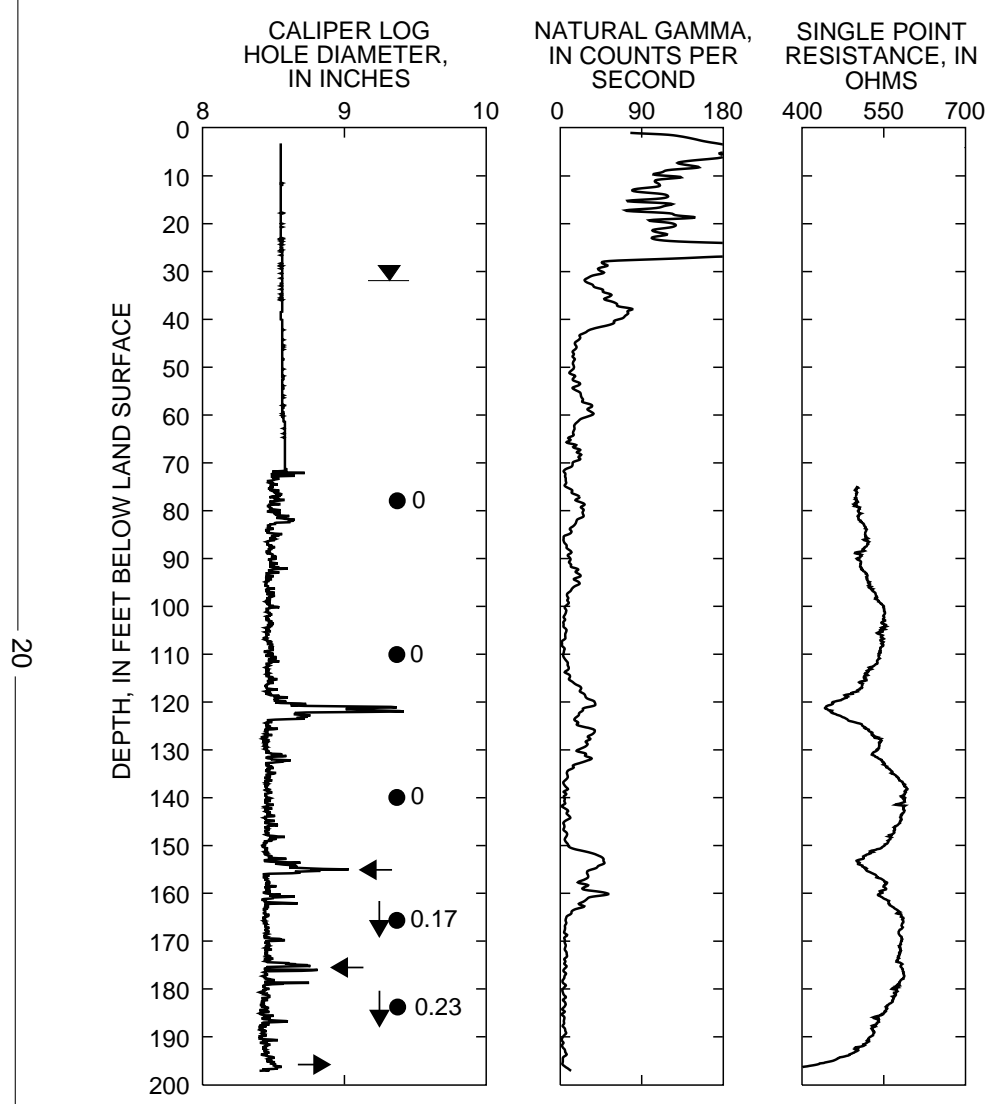
FLUID
TEMPERATURE, IN FLUD RESISTIVITY,
IN OHM-METERS
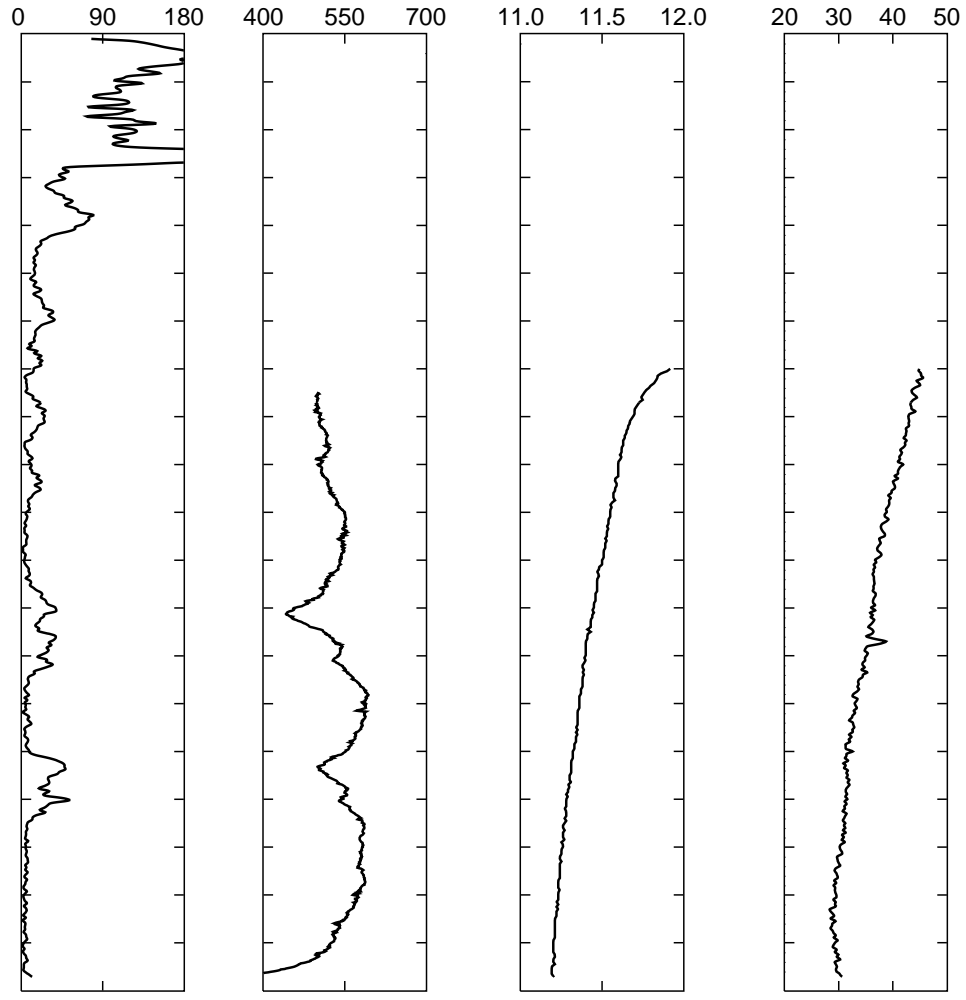

\section{EXPLANATION}

$\checkmark$ WATER LEVEL-Measured in well at the time of geophysical logging

- 0.23 BOREHOLE-FLOW MEASUREMENT UNDER NONPUMPING CONDITIONSCircle at depth of flow measurement. per minute

DIRECTION OF VERTICAL BOREHOLE FLOWDownward arrow indi flow

$\longleftarrow$ FLOW INTO BOREHOLEArrow pointing toward caliper log ndicates flow into borehole

$\longrightarrow$ FLOW OUT OF BOREHOLE-

Arrow pointing away from caliper log indicates flow out of borehole

Figure 13. Borehole geophysical logs from well RW-3 (CH-5806), AIW Frank/Mid-County Mustang Superfund Site, Chester County, Pennsylvania. 


\section{Aquifer-Isolation Test of Interval 1 (164 to 198 Feet Below Land Surface)}

For isolated interval 1, the top packer was centered at $164 \mathrm{ft}$ bls and the bottom packer was not inflated (fig. 2A). The interval of borehole isolated was from $164 \mathrm{ft}$ bls to the bottom of the well at $198 \mathrm{ft}$ bls. This interval includes the water-producing fracture at $174-179 \mathrm{ft}$ bls and the water-receiving fracture at $194-198 \mathrm{ft}$ bls. Isolated interval 1 is a high-yielding zone; it was pumped at an estimated average rate of $25 \mathrm{gal} / \mathrm{min}$ for 107 minutes. The pumping rate was estimated by making periodic volumetric measurements because sediment in the discharge water clogged the in-line flowmeter. Drawdown in the isolated interval was $3.52 \mathrm{ft}$, and drawdown in the interval above the packer was $2.34 \mathrm{ft}$. The specific capacity of interval 1 is 7.1 (gal/min)/ft. The hydrographs for the intervals above and below the packer are shown in figure 14. The hydrographs indicate a strong hydraulic connection outside the borehole between the isolated interval and the interval above the packer.

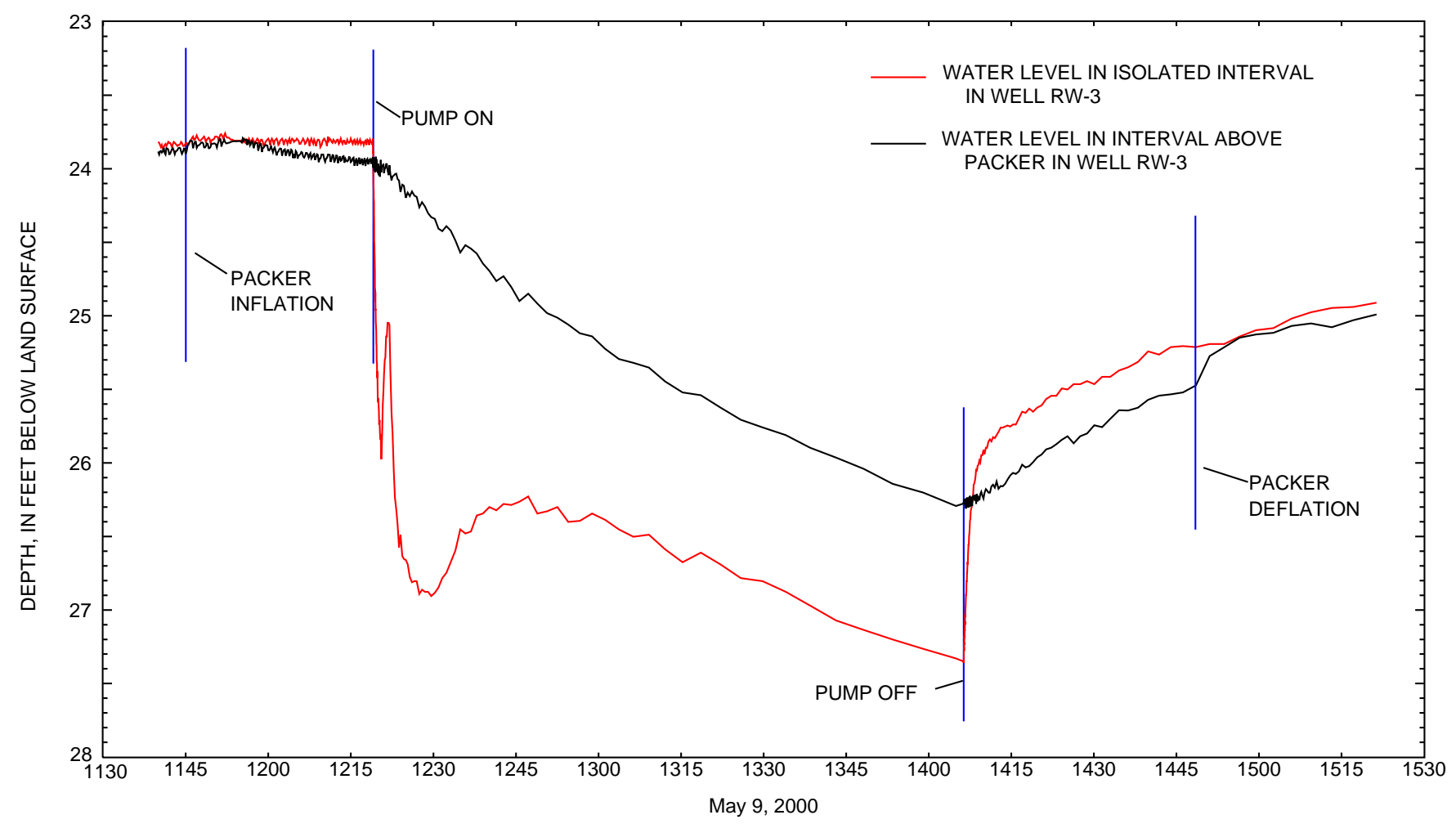

Figure 14. Hydrographs from aquifer-isolation test of interval 1 (164 to 198 feet below land surface) in well RW-3 (CH-5806), AIW Frank/Mid-County Mustang Superfund Site, Chester County, Pennsylvania. 


\section{Aquifer-Isolation Test of Interval 2 (148 to 167 Feet Below Land Surface)}

For isolated interval 2, the top packer was centered at $148 \mathrm{ft}$ bls (fig. 2B), and the interval of borehole isolated was from 148 to $167 \mathrm{ft}$ bls. This interval includes the water-producing fracture at $153-156 \mathrm{ft}$ bls. Isolated interval 2 is a very low-yielding zone; it was pumped at an estimated average rate of $0.34 \mathrm{gal} / \mathrm{min}$ for 73 minutes. The pumping rate was estimated by making periodic volumetric measurements because sediment in the discharge water clogged the in-line flowmeter. Drawdown in the interval above the packers was $0.06 \mathrm{ft}$, drawdown in the isolated interval was $54.96 \mathrm{ft}$, and drawdown in the interval below the packers was $0.49 \mathrm{ft}$. The specific capacity of interval 2 is $0.006(\mathrm{gal} / \mathrm{min}) / \mathrm{ft}$. The hydrographs for the isolated interval and the intervals above and below the packers are shown in figure 15. The hydrographs indicate no hydraulic connection outside the borehole between the isolated interval and the interval below and little hydraulic connection between the isolated interval and the interval above.

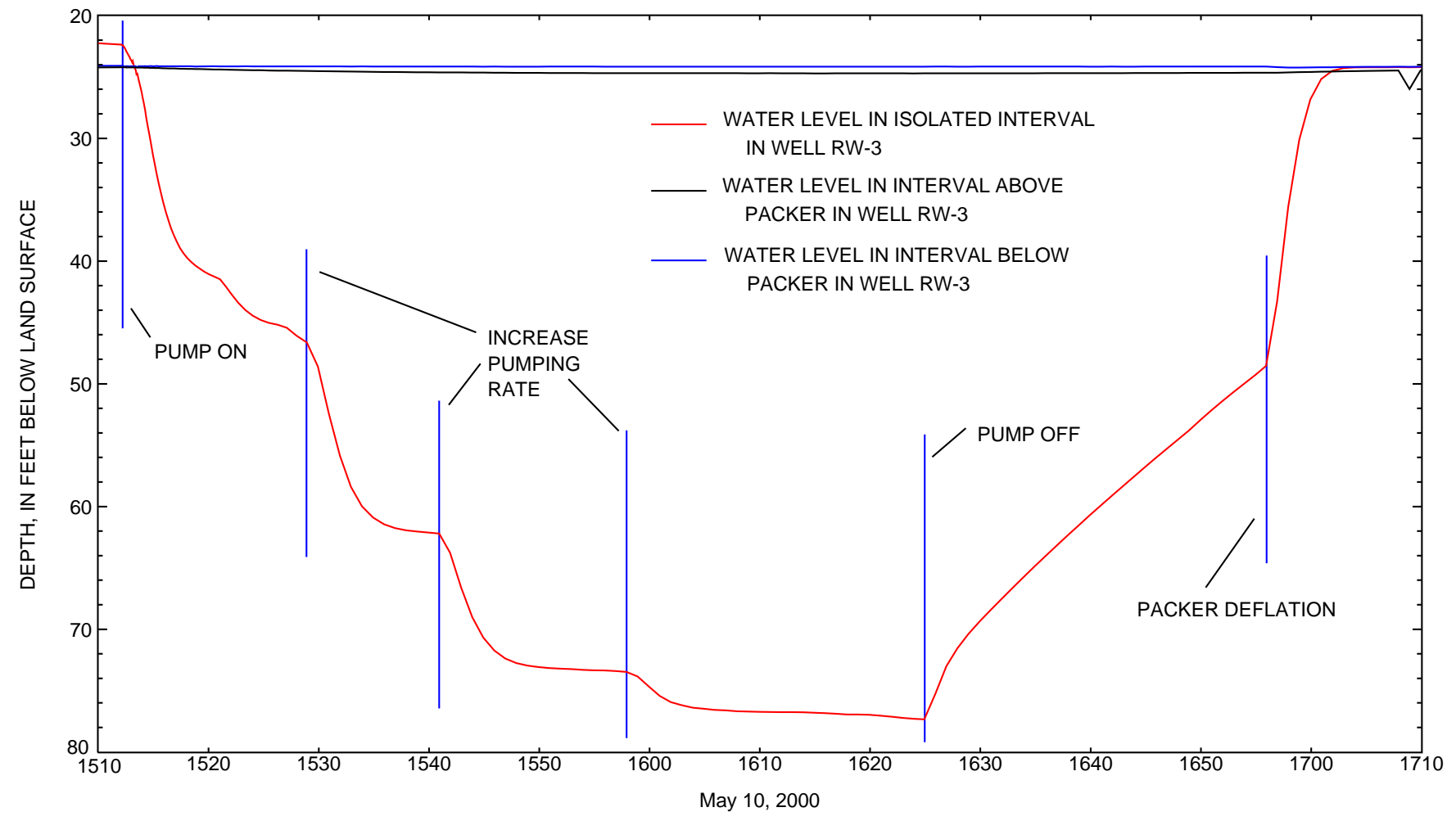

Figure 15. Hydrographs from aquifer-isolation test of interval 2 (148 to 167 feet below land surface) in well RW-3 (CH-5806), AIW Frank/Mid-County Mustang Superfund Site, Chester County, Pennsylvania. 


\section{Aquifer-Isolation Test of Interval 3 (109 to 128 Feet Below Land Surface)}

For isolated interval 3, the top packer was centered at $109 \mathrm{ft}$ bls (fig. 2B), and the interval of borehole isolated was from 109-128 ft bls. This interval includes the large fracture at $122-126 \mathrm{ft}$ bls, which was reported by the driller to yield $10 \mathrm{gal} / \mathrm{min}$. Isolated interval 3 was pumped at an average rate of $4.1 \mathrm{gal} / \mathrm{min}$ for 94 minutes. Drawdown in the interval above the packers was $10.77 \mathrm{ft}$, drawdown in the isolated interval was
$61.66 \mathrm{ft}$, and drawdown in the interval below the packers was $0.91 \mathrm{ft}$. The specific capacity of interval 3 is 0.07 (gal $/ \mathrm{min}) / \mathrm{ft}$. The hydrographs for the isolated interval and the intervals above and below the packers are shown in figure 16 . The hydrographs indicate some hydraulic connection outside the borehole between the isolated interval and the interval below and good hydraulic connection between the isolated interval and the interval above.

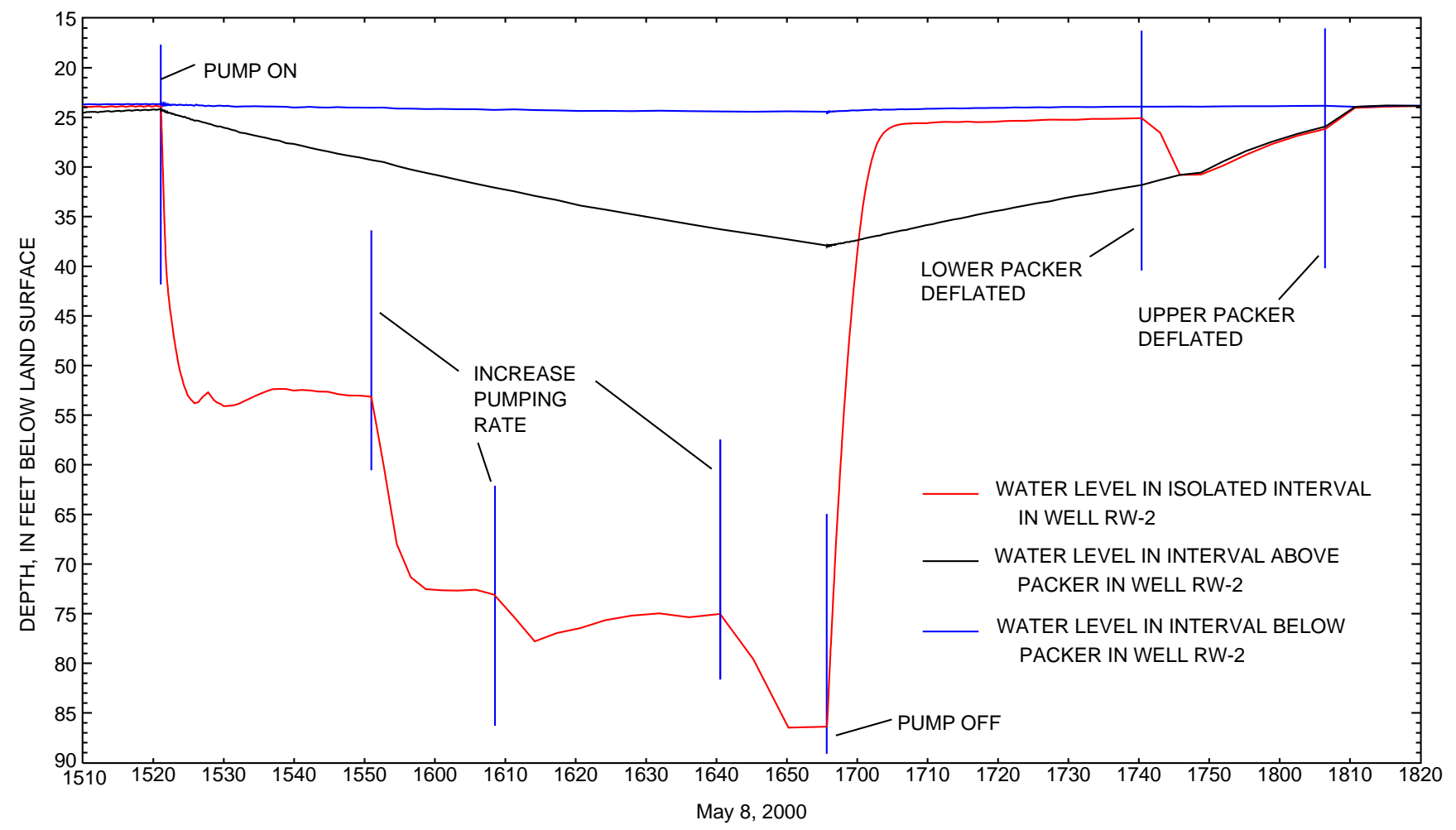

Figure 16. Hydrographs from aquifer-isolation test of interval 3 (109 to 128 feet below land surface) in well RW-3 (CH-5806), AIW Frank/Mid-County Mustang Superfund Site, Chester County, Pennsylvania. 


\section{Well RW-6 (CH-5808)}

\section{Interpretation of Borehole Geophysical Logs}

A suite of borehole geophysical logs (fig. 17) was collected in well RW-6 by the USGS. The caliper log shows the well is $248 \mathrm{ft}$ deep and is cased to $67 \mathrm{ft}$ bls. The caliper log shows major fractures at 90-92, 118-119, 180-182, and 206-208 ft bls. Heatpulse-flowmeter measurements were made under nonpumping conditions at 79, 106, 124, 150, 162, 170, 199, and $214 \mathrm{ft}$ bls (table 8). On the basis of the geophysical logs and heatpulse-flowmeter measurements, water enters the borehole through the fracture at $118-119 \mathrm{ft}$ bls $(2.4 \mathrm{gal} / \mathrm{min})$ and flows both upward and downward. Water flowing upward from the fracture at 118-119 $\mathrm{ft}$ bls exits the borehole through the fracture at 90-92 ft bls $(1.1 \mathrm{gal} / \mathrm{min})$. Some of the water flowing downward from the fracture at 118-119 ft bls exits the borehole through a minor fracture at $169 \mathrm{ft}$ bls (about $0.4 \mathrm{gal} / \mathrm{min}$ ) but most continues to flow downward (about $0.9 \mathrm{gal} / \mathrm{min}$ ). Water also enters the borehole through the fracture at 180-184 ft bls (about $0.5 \mathrm{gal} / \mathrm{min}$ ) and flows downward. The water flowing down the borehole exits the borehole through the fracture at 206-208 ft bls $(1.4 \mathrm{gal} / \mathrm{min})$. The principal water-bearing zones in well RW-6 are at 90-92, 118-119, 169, 180-182, and 206-208 ft bls.

\section{Aquifer-Isolation Tests}

On the basis of the borehole geophysical logs and heatpulse-flowmeter measurements, four intervals were selected for isolation (table 9). The distance between the center of the top packer and the center of the bottom packer was $19 \mathrm{ft}$. During pumping of the isolated zone, water levels in nearby wells OB-4 and OB-3 were monitored in addition to water levels in well RW-6.

Table 8. Heatpulse-flowmeter measurements made in well RW-6 (CH-5808), AlW Frank/Mid-County Mustang Superfund Site, Chester County, Pennsylvania

\begin{tabular}{ccc}
\hline $\begin{array}{c}\text { Depth } \\
\text { (feet below } \\
\text { land surface) }\end{array}$ & $\begin{array}{c}\text { Flow } \\
\text { (gallons per minute) }\end{array}$ & $\begin{array}{c}\text { Flow } \\
\text { direction }\end{array}$ \\
\hline 79 & 0 & Up \\
106 & 1.1 & Down \\
124 & 1.3 & Down \\
150 & 1.4 & Down \\
162 & 1.3 & Down \\
170 & .87 & Down \\
199 & 1.4 & \\
214 & 0 & \\
\hline
\end{tabular}

Table 9. Intervals isolated and specific capacities for well RW-6 (CH-5808), AIW Frank/Mid-County Mustang Superfund Site, Chester County, Pennsylvania

\begin{tabular}{|c|c|c|c|c|c|}
\hline $\begin{array}{l}\text { Interval } \\
\text { number }\end{array}$ & $\begin{array}{c}\text { Isolated interval } \\
\text { (feet below land surface) }\end{array}$ & $\begin{array}{c}\text { Isolated fracture } \\
\text { (feet below land surface) }{ }^{1}\end{array}$ & $\begin{array}{l}\text { Pumping time } \\
\text { (minutes) }\end{array}$ & $\begin{array}{l}\text { Average pumping rate } \\
\text { (gallons per minute) }\end{array}$ & $\begin{array}{l}\text { Specific capacity } \\
\text { (gallons per minute per foot) }\end{array}$ \\
\hline 1 & $197-216$ & $206-208$ & 94 & 13.1 & 0.16 \\
\hline 2 & 177-196 & $180-182$ & 90 & 7.5 & .09 \\
\hline 3 & $106-125$ & $118-119$ & 127 & 223.3 & 2.3 \\
\hline 4 & 80-99 & $90-92$ & 96 & 225 & 3.5 \\
\hline
\end{tabular}




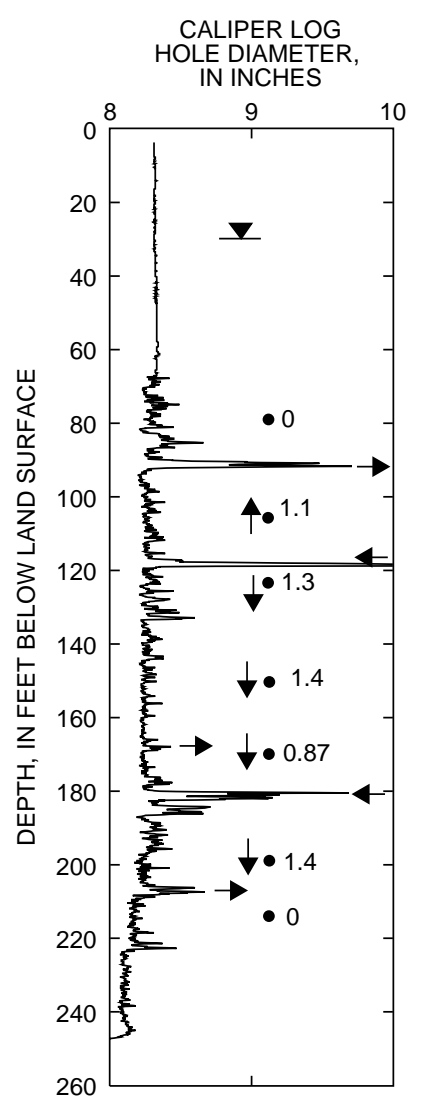

NATURAL GAMMA, SINGLE POINT
IN COUNTS PER COUNTS PER SECOND RESISTANCE,
OHMS

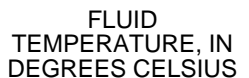

FLUID RESISTIVITY,
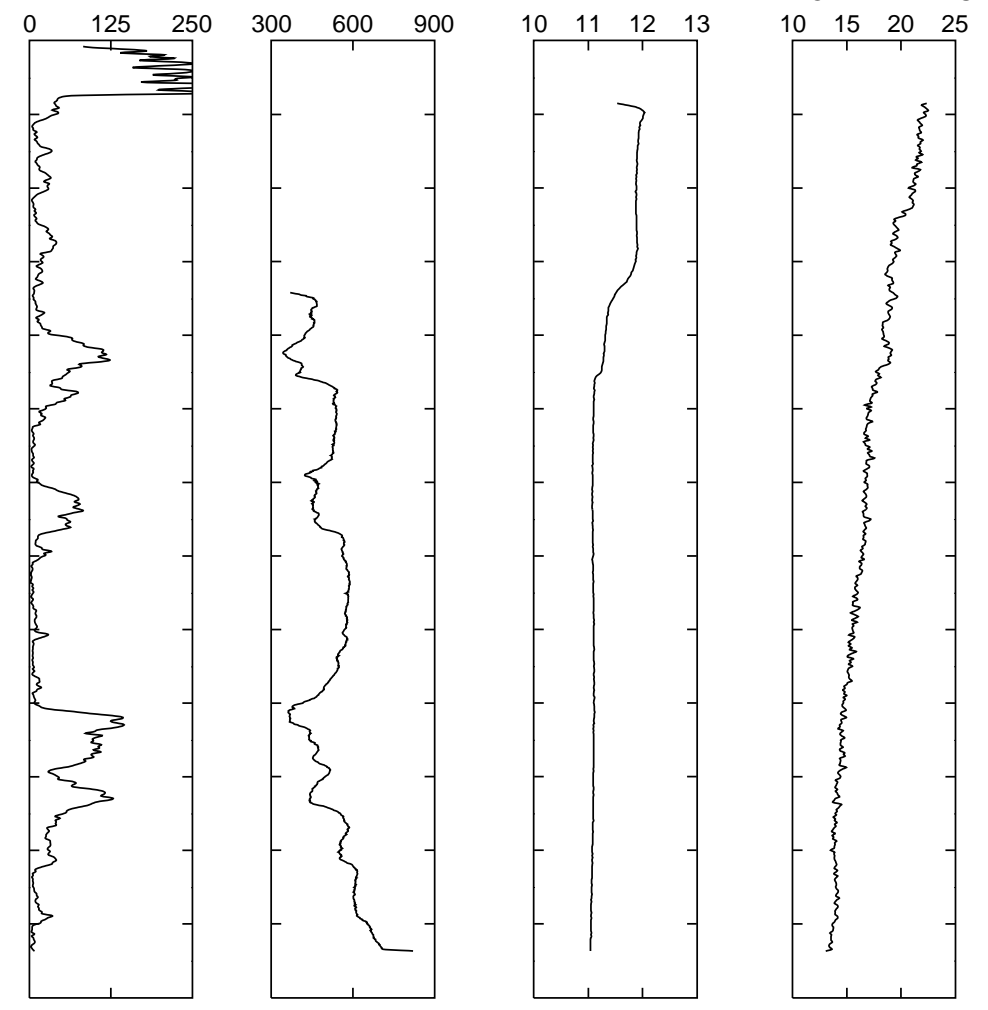

\section{EXPLANATION}

$\boldsymbol{\nabla}$ WATER LEVEL-Measured in well at the time of geophysical logging

- 1.4 BOREHOLE-FLOW MEASUREMENT UNDER NONPUMPING CONDITIONSCircle at depth of flow measurement. per minute

4 DIRECTION OF VERTICAL BOREHOLE FLOWDownward arrow indicates downward flow
down

4 FLOW INTO BOREHOLEArrow pointing toward caliper log indicates flow into borehole

$\rightarrow$ FlOW OUT OF BOREHOLE-

Arrow pointing away from caliper log indicates flow out of borehole

Figure 17. Borehole geophysical logs from well RW-6 (CH-5808), AIW Frank/Mid-County Mustang Superfund Site, Chester County, Pennsylvania. 


\section{Aquifer-Isolation Test of Interval 1 (197 to 216 Feet Below Land Surface)}

For isolated interval 1, the top packer was centered at $197 \mathrm{ft}$ bls, and the lower packer was not inflated (fig. 2A). The interval of borehole isolated was from $197 \mathrm{ft}$ bls to $216 \mathrm{ft}$ bls. This interval includes the major water-receiving fracture at 206-208 ft bls. Before packer inflation, the depth to water in the open borehole was $11.45 \mathrm{ft}$ bls. Eighty-five minutes after packer inflation, the depth to water in the isolated interval decreased $1.59 \mathrm{ft}$. The depth to water in the interval above the packer increased $0.10 \mathrm{ft}$. This is consistent with the interpretation of the borehole geophysical logs and downward borehole flow shown by the heatpulse-flowmeter measurements, which indicate the isolated water-producing fracture at 206-208 ft bls has a lower head than the water-receiving fractures above.
Isolated interval 1 was initially pumped at $20.5 \mathrm{gal} / \mathrm{min}$, but the water level rapidly dropped below the level of the transducer, which was set at $115.57 \mathrm{ft}$ bls (drawdown greater than $102.54 \mathrm{ft}$ ). The pumping rate was then reduced to $13 \mathrm{gal} / \mathrm{min}$; the maximum drawdown at that rate was $80.65 \mathrm{ft}$. Isolated interval 1 was pumped at a time-weighted average rate of $13.1 \mathrm{gal} / \mathrm{min}$ for 94 minutes. Drawdown in the interval above the packers was $0.11 \mathrm{ft}$, and drawdown in the interval below the packers was $37.66 \mathrm{ft}$. The specific capacity of interval 1 is $0.16(\mathrm{gal} / \mathrm{min}) / \mathrm{ft}$. The hydrographs for well RW-6 and the observation wells are shown in figure 18 . The hydrographs indicate a hydraulic connection outside the borehole between the isolated interval and interval below the packer. No drawdown was observed in the observation wells.

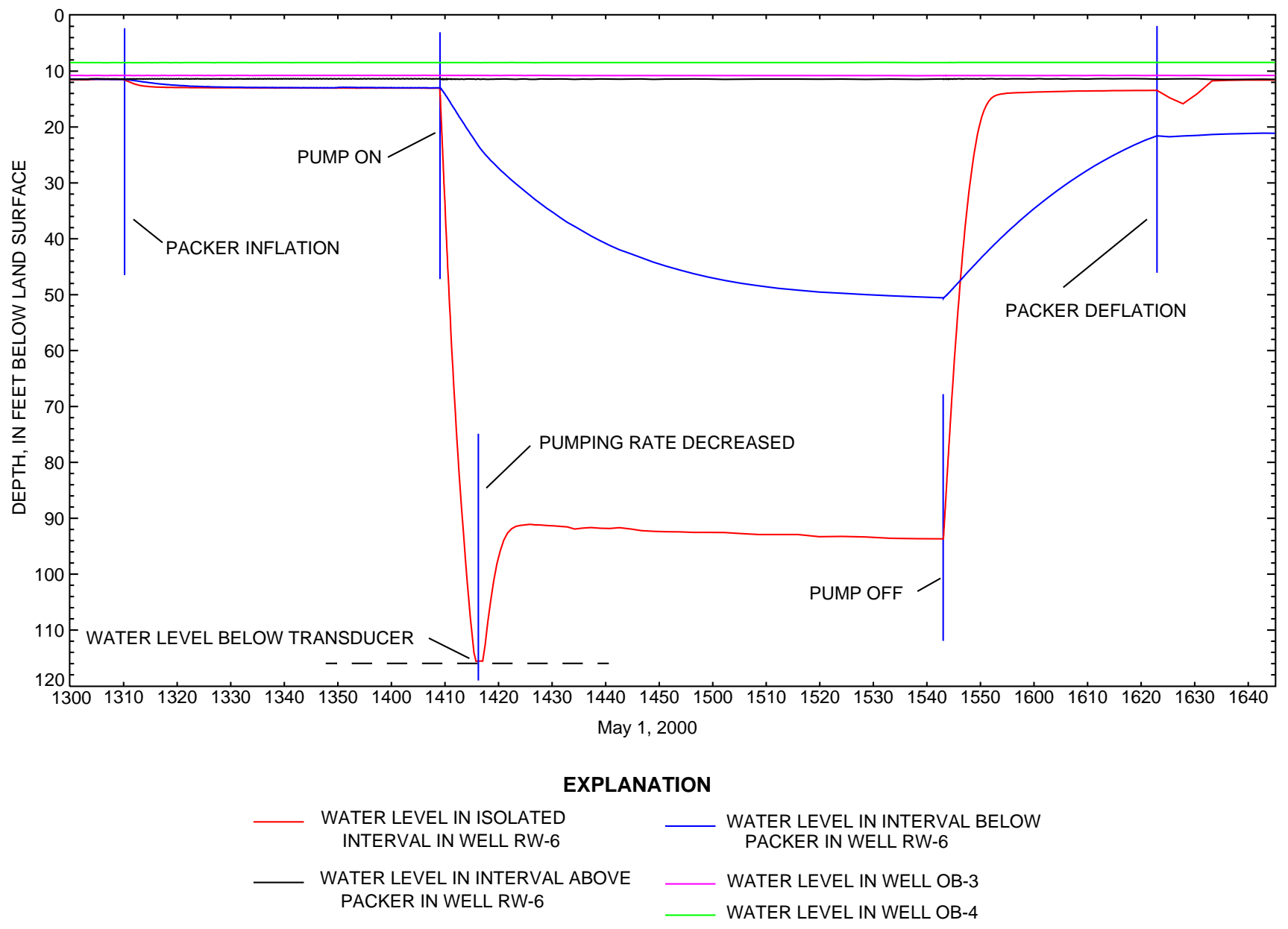

Figure 18. Hydrographs from aquifer-isolation test of interval 1 (197 to 216 feet below land surface) in well RW- 6 (CH-5808), AIW Frank/Mid-County Mustang Superfund Site, Chester County, Pennsylvania. 


\section{Aquifer-Isolation Test of Interval 2 (177 to 196 Feet Below Land Surface)}

For isolated interval 2, the top packer was set at $177 \mathrm{ft}$ bls (fig. 2B), and the interval of borehole isolated was from 177 to $196 \mathrm{ft}$ bls. This interval includes the major water-producing fracture at $180-182 \mathrm{ft}$ bls. Before packer inflation, the depth to water in the open borehole was $11.57 \mathrm{ft}$ bls. Fifty-eight minutes after packer inflation, depth to water in the interval above the packer increased $0.06 \mathrm{ft}$, depth to water in the isolated interval decreased $0.84 \mathrm{ft}$, and depth to water in the interval below the packer decreased $1.08 \mathrm{ft}$. This is consistent with the interpretation of the borehole geophysical logs, which indicate the isolated water-producing fracture at 180-182 ft bls has a higher head than the water-producing fractures below and a lower head than the water-producing fractures above.

Isolated interval 2 was pumped at a time-weighted average rate of $7.5 \mathrm{gal} / \mathrm{min}$ for 90 minutes. The initial pumping rate was $22 \mathrm{gal} / \mathrm{min}$, but the water level in the isolated interval dropped below the transducer, which was set at $114.50 \mathrm{ft}$ bls. The pumping rate was then decreased to $5.4 \mathrm{gal} / \mathrm{min}$ for the remainder of the test. Drawdown after the rate increase in the interval above the packers was $0.20 \mathrm{ft}$, drawdown in the isolated interval was $84.74 \mathrm{ft}$, and drawdown in the interval below the packers was $5.46 \mathrm{ft}$. The specific capacity of interval 2 is 0.09 (gal/min)/ft. The hydrographs for the isolated interval and the intervals above and below the packers are shown in figure 19. The hydrographs indicate a hydraulic connection outside the borehole between the isolated interval and the interval below the packer. No drawdown was observed in the observation wells.

\section{Aquifer-Isolation Test of Interval 3 (106 to 125 Feet Below Land Surface)}

For isolated interval 3, the top packer was centered at $106 \mathrm{ft}$ bls (fig. 2A), and the interval of borehole isolated was from 106 to $125 \mathrm{ft}$ bls. This interval includes the major water-producing fracture at 118-119 $\mathrm{ft}$ bls. Before packer inflation, the depth to water in the open borehole was $11.76 \mathrm{ft}$ bls. Fifty-four minutes after packer inflation, depth to water in the

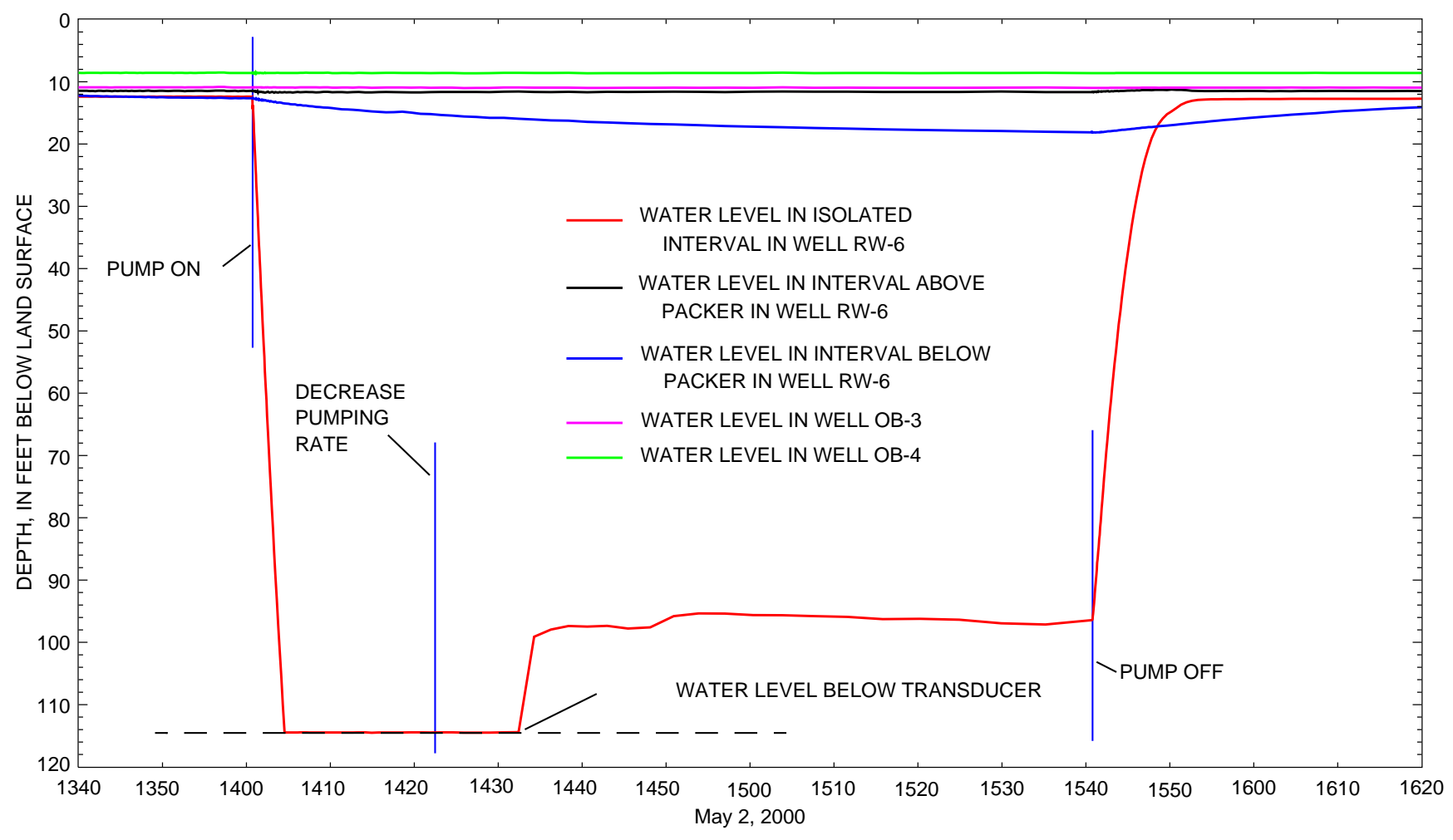

Figure 19. Hydrographs from aquifer-isolation test of interval 2 (177 to 196 feet below land surface) in well RW-6 (CH-5808), AIW Frank/Mid-County Mustang Superfund Site, Chester County, Pennsylvania. 
interval above the packer increased $0.17 \mathrm{ft}$, depth to water in the isolated interval decreased $0.05 \mathrm{ft}$, and depth to water in the interval below the packer increased $0.67 \mathrm{ft}$. This is consistent with the interpretation of the borehole geophysical logs, which indicate the isolated water-producing fracture at $118-119 \mathrm{ft}$ bls has a higher head than the water-receiving fractures above and below.

Isolated interval 3 is a high-yielding zone; it was pumped at an estimated average rate of $23.3 \mathrm{gal} / \mathrm{min}$ for 127 minutes with a maximum drawdown of $9.98 \mathrm{ft}$ (fig. 20). The pumping rate was estimated by making periodic volumetric measurements because sediment in the discharge water clogged the in-line flowmeter.
Drawdown in the interval above the packers was $0.91 \mathrm{ft}$, and drawdown in the interval below the packers was $2.19 \mathrm{ft}$. The specific capacity of interval 3 is 2.3 (gal/min)/ft. The hydrographs for well RW-6 and the observation wells are shown in figure 20. The hydrographs indicate a hydraulic connection outside the borehole between the isolated interval and the intervals above and below the isolated interval. Drawdown in wells OB-3 and OB-4 caused by pumping the isolated interval was $0.15 \mathrm{ft}$ and $0.36 \mathrm{ft}$, respectively, indicating a hydraulic connection between the isolated interval 106-125 ft bls in well RW-6 and the observation wells.

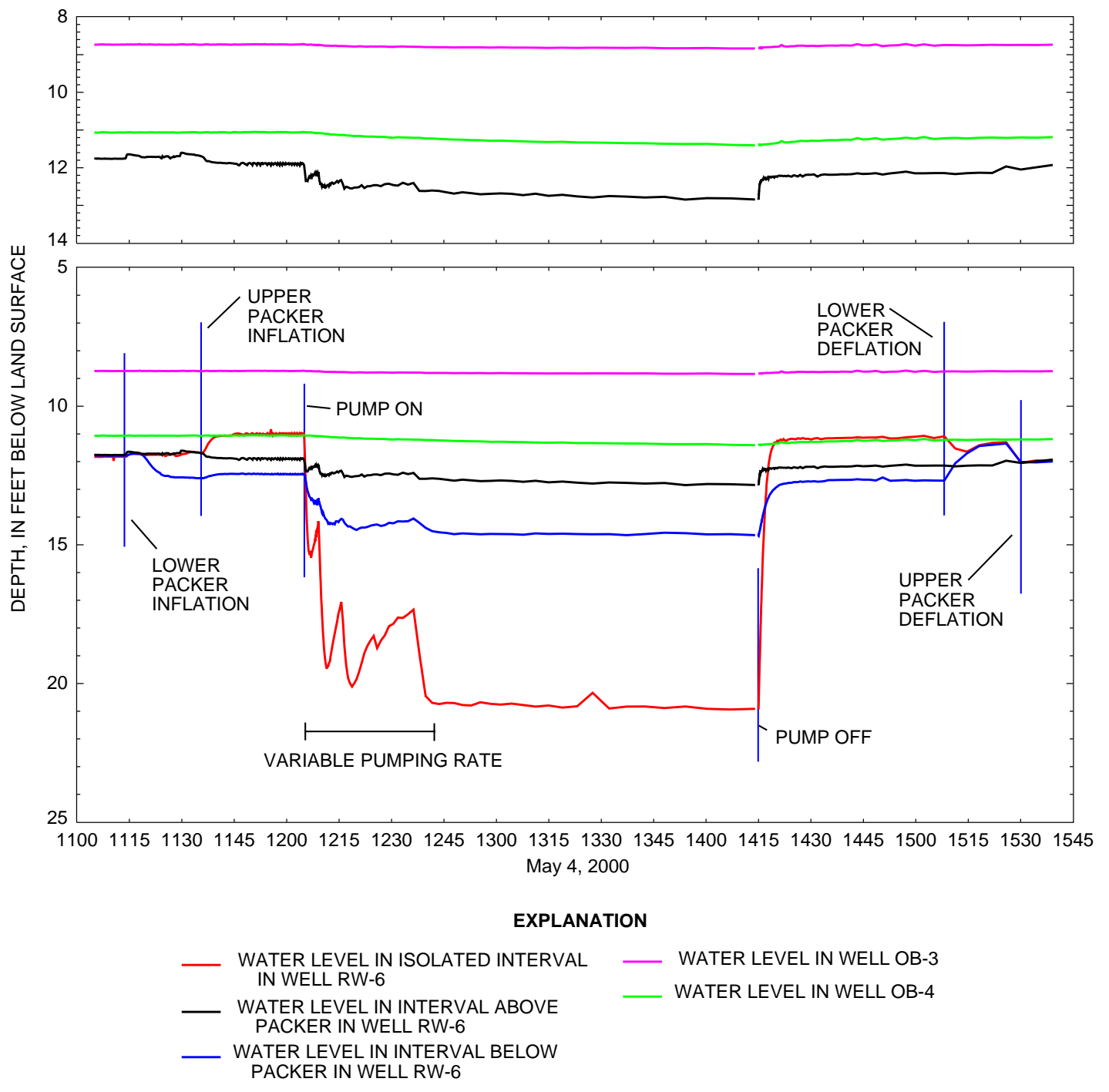

Figure 20. Hydrographs from aquifer-isolation test of interval 3 (106 to 125 feet below land surface) in well RW-6 (CH-5808), AIW Frank/Mid-County Mustang Superfund Site, Chester County, Pennsylvania. 


\section{Aquifer-Isolation Test of Interval 4 (80 to 99 Feet Below Land Surface)}

For isolated interval 4, the top packer was centered at $80 \mathrm{ft}$ bls (fig. 2B), and the interval of borehole isolated was from 80 to $99 \mathrm{ft}$ bls. This interval includes the water-receiving fracture at 90-92 ft bls. Before packer inflation, the depth to water in the open borehole was $11.62 \mathrm{ft}$ bls. Thirty-seven minutes after packer inflation, depth to water in the isolated interval decreased $0.15 \mathrm{ft}$, depth to water in the interval above the packers increased $0.12 \mathrm{ft}$, and depth to water in the interval below the packers increased $0.57 \mathrm{ft}$. This is consistent with the interpretation of the borehole geophysical logs, which indicate the isolated water-receiving fracture at 90-92 ft bls has a lower head than the water-producing fracture below.
Isolated interval 4 is a high-yielding zone; it was pumped at an estimated average rate of $25 \mathrm{gal} / \mathrm{min}$ for 96 minutes with a maximum drawdown of $7.24 \mathrm{ft}$ (fig. 21). The pumping rate was estimated by making periodic volumetric measurements because sediment in the discharge water clogged the in-line flowmeter. Drawdown in the isolated interval above the packers was $1.17 \mathrm{ft}$, and drawdown in the interval below the packers was $0.66 \mathrm{ft}$. The specific capacity of interval 4 is 3.5 (gal/min)/ft. The hydrographs for well RW-6 and the observation wells are shown in figure 21 . The hydrographs indicate a hydraulic connection outside the borehole between the isolated interval and the intervals above and below the isolated interval. Drawdown in well OB-4 caused by pumping the isolated interval was $0.20 \mathrm{ft}$, indicating a hydraulic connection between the isolated interval 80-99 ft bls in well RW-6 and well OB-4.

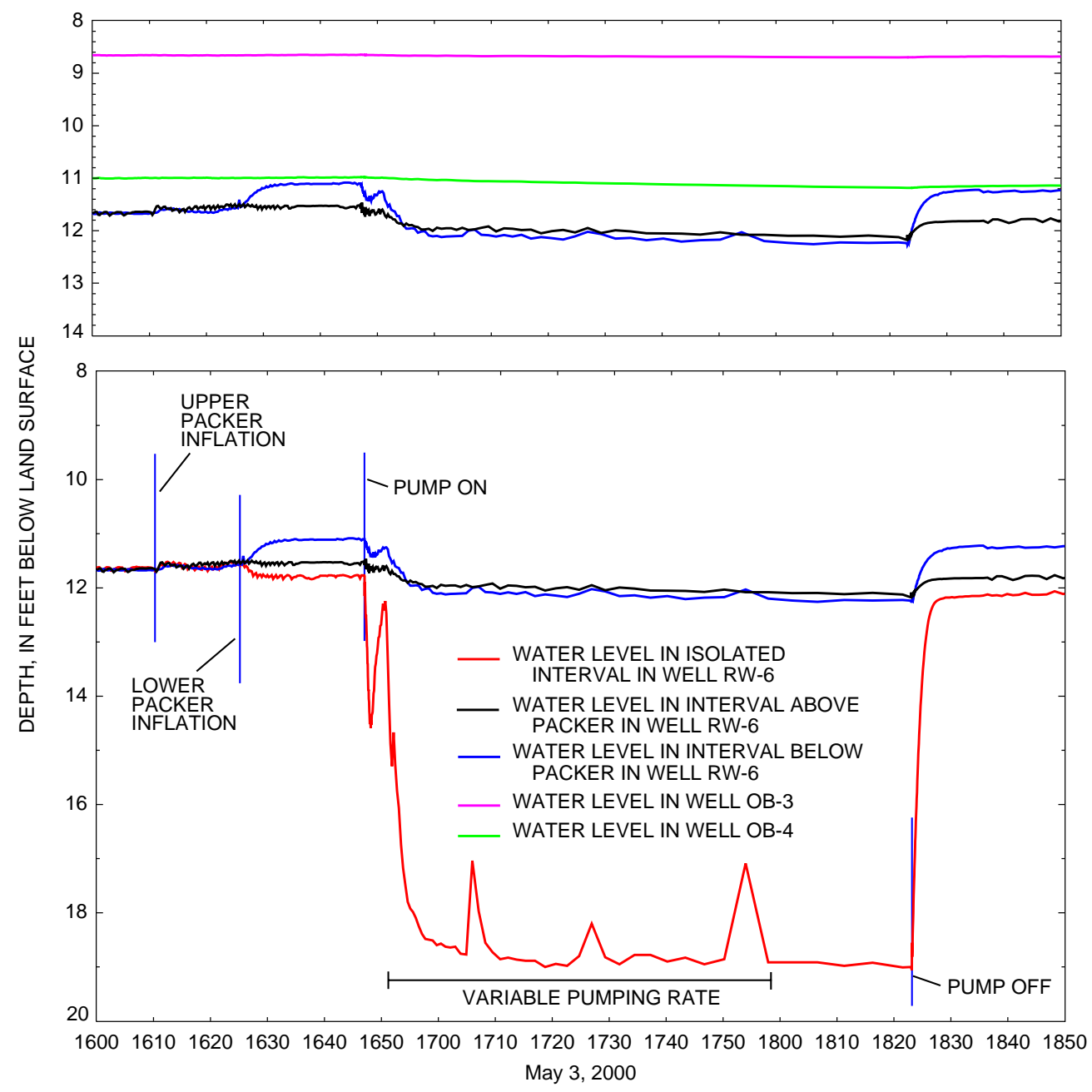

Figure 21. Hydrographs from aquifer-isolation test of interval 4 (80 to 99 feet below land surface) in well RW-6 (CH-5808), AIW Frank/Mid-County Mustang Superfund Site, Chester County, Pennsylvania. 


\section{EVALUATION OF BOREHOLE GEOPHYSICAL LOGS FOR WELL RW-1 (CH-5804)}

A suite of borehole geophysical logs (fig. 22) was collected in well RW-1 by the USGS. The caliper log shows the well is $297 \mathrm{ft}$ deep and is cased to $40 \mathrm{ft}$ bls. The caliper log shows a major fracture at $50-52 \mathrm{ft} \mathrm{bls}$ and minor fractures at 59-60, 65, and 169-171 ft bls. The fracture at 50-52 ft bls appears to be the major water-producing fracture. The fluid-resistivity and fluid-temperature logs do not indicate borehole flow under nonpumping conditions. This was confirmed with heatpulse-flowmeter measurements made at 68, 100,164, and $244 \mathrm{ft}$ bls that showed no measurable flow.
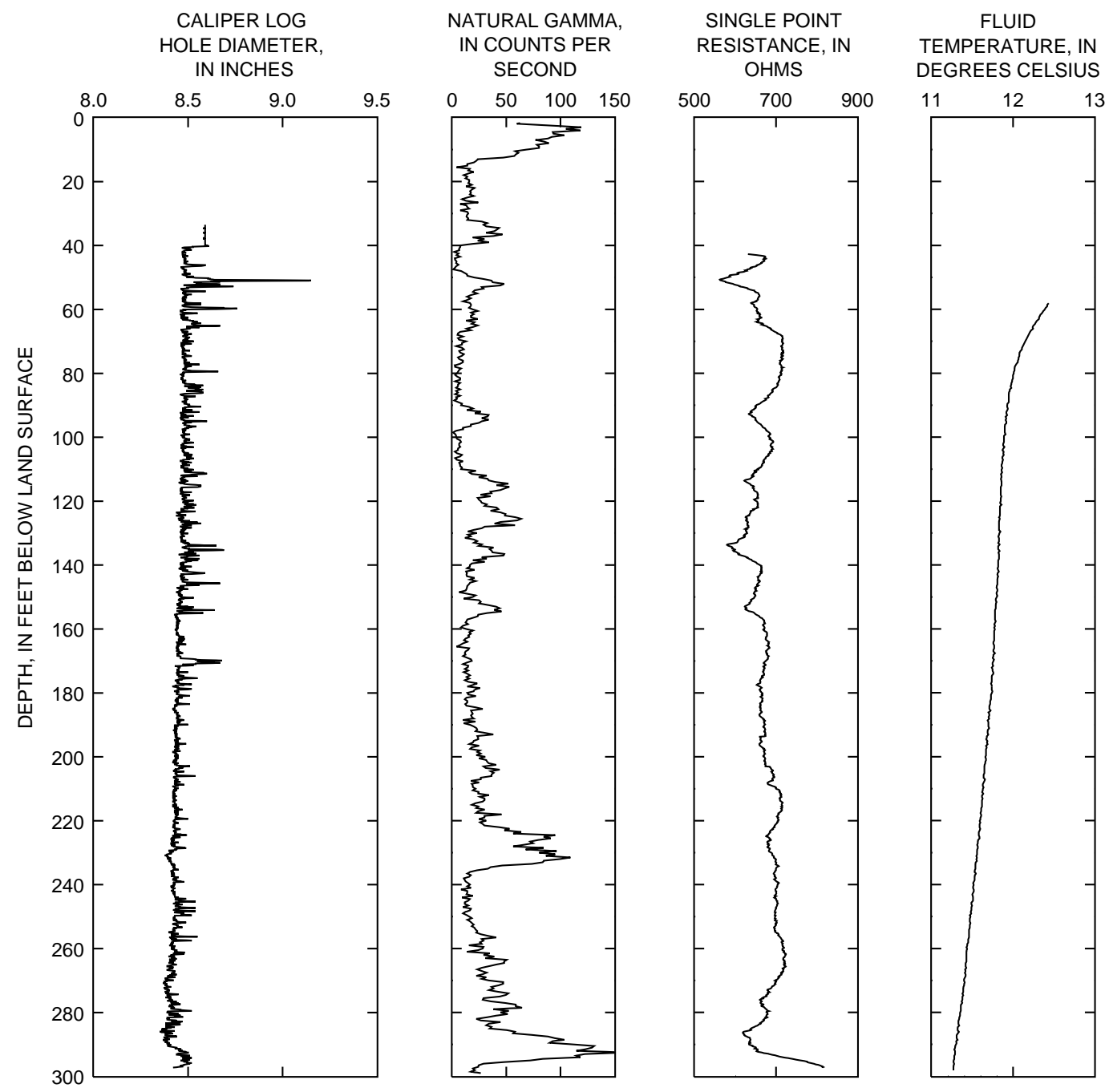

FLUID RESISTIVITY,
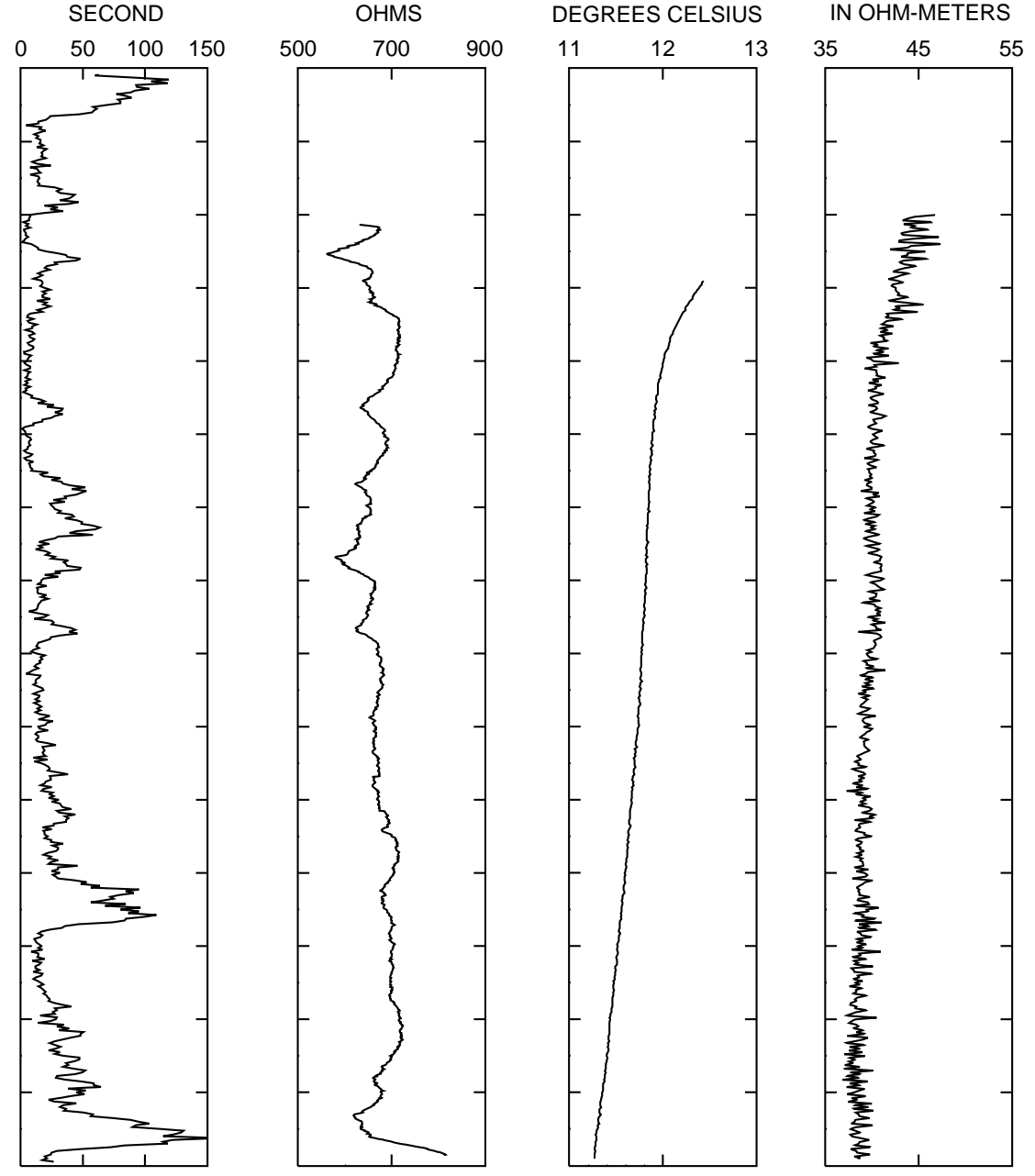

Figure 22. Borehole geophysical logs from well RW-1 (CH-5804), AIW Frank/Mid-County Mustang Superfund Site, Chester County, Pennsylvania. 


\section{EVALUATION OF BOREHOLE GEOPHYSICAL LOGS FOR WELL RW-4 (CH-5807)}

A suite of borehole geophysical logs (fig. 23) was collected in well RW-4 by the USGS. The caliper log shows the well is $298 \mathrm{ft}$ deep and is cased to $18 \mathrm{ft}$ bls. The caliper log shows a major fracture at $24-26 \mathrm{ft}$ bls and several minor fractures. The fluid-resistivity and fluid-temperature logs do not indicate borehole flow under nonpumping conditions. This was confirmed with heatpulse-flowmeter measurements made at 44 , 90,170 , and $260 \mathrm{ft}$ bls that showed no measurable flow.

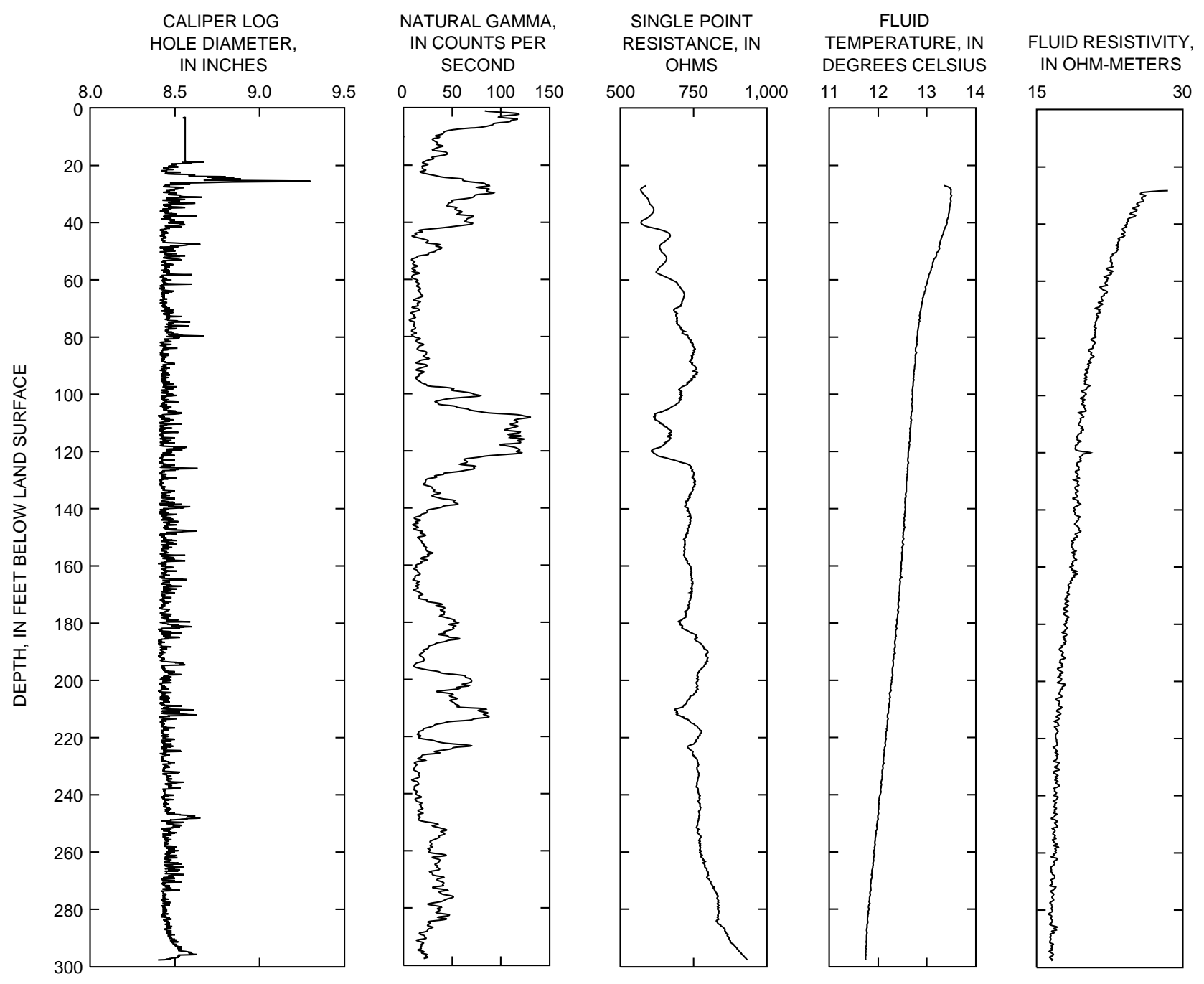

Figure 23. Borehole geophysical logs from well RW-4 (CH-5807), AIW Frank/Mid-County Mustang Superfund Site, Chester County, Pennsylvania. 
EVALUATION OF BOREHOLE GEOPHYSICAL LOGS FOR WELL OB-5 (CH-5447)

A suite of borehole geophysical logs (fig. 24) was collected in well OB- 5 by the USGS. The caliper log shows the well is $38 \mathrm{ft}$ deep and is cased to $21.5 \mathrm{ft}$ bls.
The caliper log shows a large fracture zone from the bottom of the casing to the bottom of the well. The well may have filled to $38 \mathrm{ft}$ bls with sediment from this fracture zone.
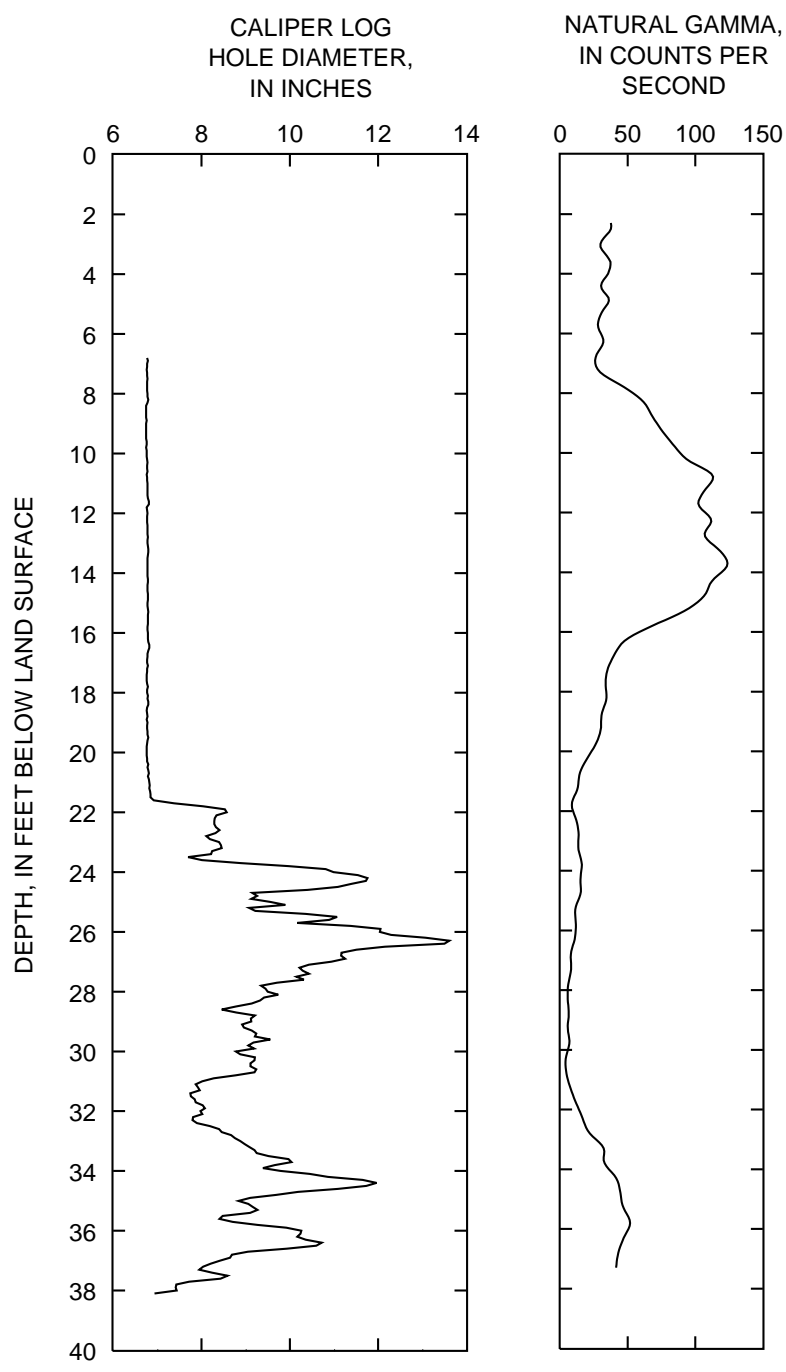

SINGLE POINT

RESISTANCE, IN OHMS

TEMPERATURE, IN DEGREES CELSIUS

FLUID RESISTIVITY,

$\begin{array}{llll}0 & 50 & 100 & 150\end{array}$
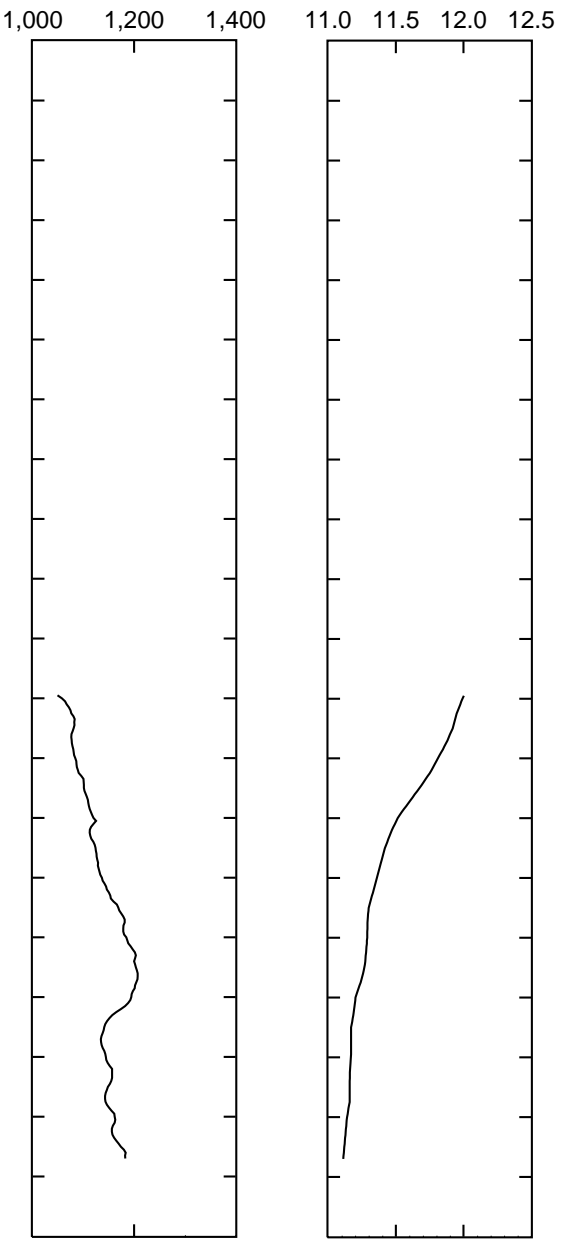

IN OHM-METERS
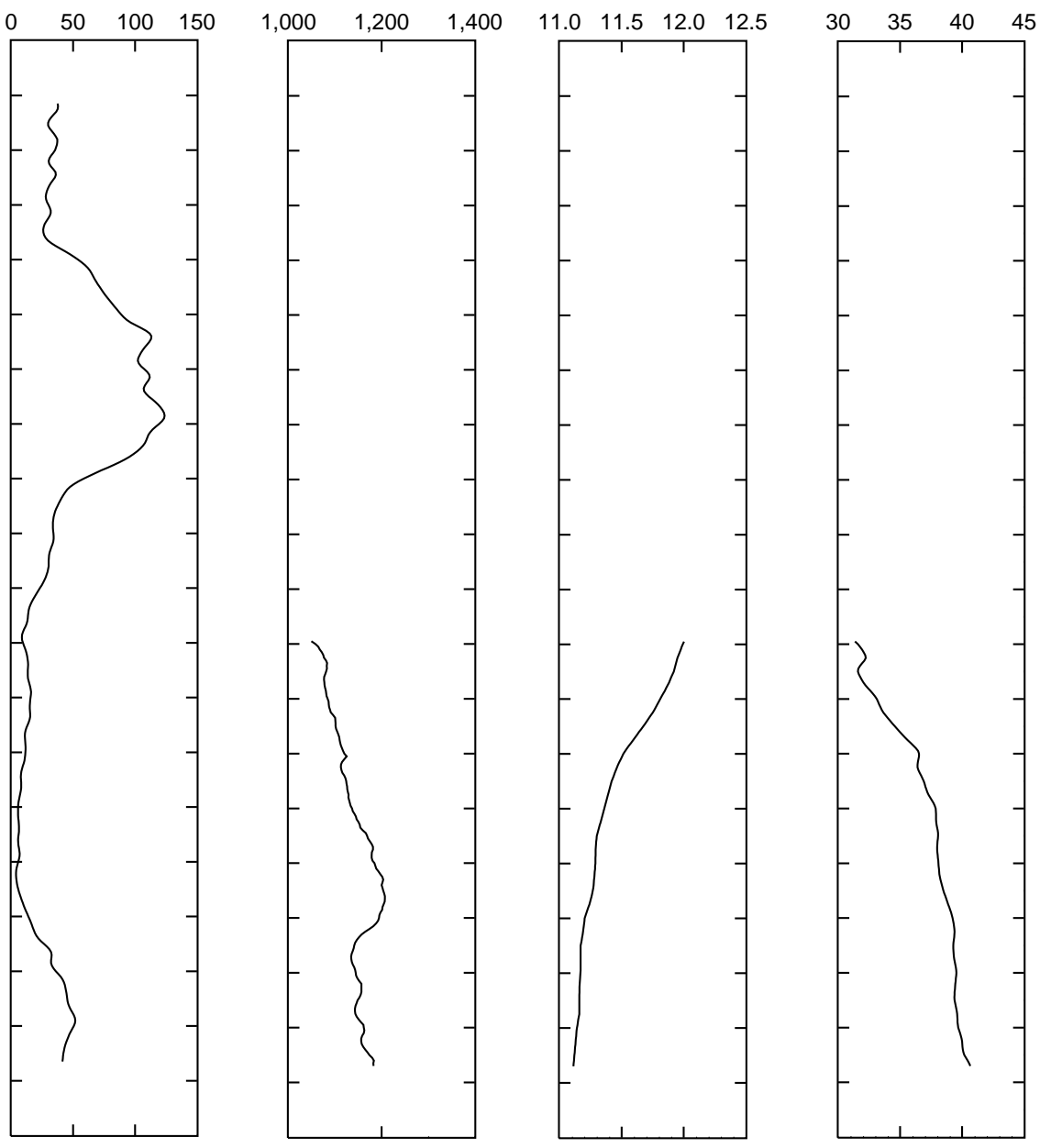

Figure 24. Borehole geophysical logs from well OB-5 (CH-5447), AIW Frank/Mid-County Mustang Superfund Site, Chester County, Pennsylvania. 


\section{SUMMARY AND CONCLUSIONS}

Borehole geophysical logs, heatpulse-flowmeter measurements, and aquifer-isolation tests were used to characterize the ground-water-flow system at the AIW Frank/Mid-County Mustang Superfund Site in Chester County, $\mathrm{Pa}$. The site is underlain by fractured carbonate rocks.

Caliper, natural-gamma, single-point-resistance, fluid-resistivity, and fluid-temperature logs were collected in six wells. An acoustic borehole televiewer and borehole deviation log were run in one well. The direction and rate of borehole-fluid movement were measured with a high-resolution heatpulse flowmeter for both nonpumping and pumping conditions in four wells. The heatpulse flowmeter was used to determine the hydraulically active fractures in the logged wells. The logs and heatpulse-flowmeter measurements were used to locate water-bearing fractures, determine probable zones of vertical borehole-fluid movement, and determine the depth to set straddle packers.

The heatpulse-flowmeter measurements confirmed the location of water-bearing zones identified by the other logs and showed flow within the borehole during nonpumping conditions in three of the four wells tested. Flow rates up to $1.4 \mathrm{gal} / \mathrm{min}$ were measured. Flow was upward in well RW-3, and both upward and downward in wells RW-2 and RW-6.

Aquifer-isolation tests, commonly known as packer tests, were conducted in four wells to determine depth-discrete specific capacity values, to obtain depth-discrete water samples, and to determine the effect of pumping an individual fracture or fracture zone on water levels in nearby wells. Water-level data collected during aquifer-isolation tests were consistent with and confirmed interpretations of borehole geophysical logs and heatpulse-flowmeter measurements. Seven of the 13 fractures identified as water-producing or water-receiving zones by borehole geophysical methods produced water at a rate equal to or greater than $7.5 \mathrm{gal} / \mathrm{min}$ when isolated and pumped.

The drawdown in nearby observation wells, and the number of wells affected by pumping isolated fractures in well EW-5, decreased with depth. For well RW-2, pumping the shallowest isolated interval caused drawdown in all five observation wells, while pumping the four deeper isolated intervals caused drawdown only in observation well OB-2S. For well RW-6, pumping the uppermost two isolated intervals caused drawdown in nearby observation wells.
The specific capacity of isolated fractures range over three orders of magnitude from 0.005 to 7.1 (gal/min)/ft. This is typical of fractured-rock aquifers. Vertical distribution of specific capacity between land surface and $298 \mathrm{ft}$ bls is not related to depth. The four highest specific capacities, in descending order, are at depths of 174-198, 90-92, 118-119, and 34-37 ft bls.

\section{REFERENCES CITED}

Bascom, Florence, and Stose, G.W., 1938, Geology and mineral resources of the Honeybrook and Phoenixville quadrangles, Pennsylvania: U.S. Geological Survey Bulletin 891, 145 p.

Conger, R.W., Goode, D.J., and Sloto, R.A., 2000, Evaluation of geophysical logs and slug tests, phase II, AIW Framk/Mid-County Mustang Superfund Site, Chester County, Pennsylvania: U.S. Geological Survey Open-File Report 99-452, $28 \mathrm{p}$.

Halliburton NUS, Inc., 1991, Draft remedial investigation/feasibility study project operations plan, AIW / Frank Site, Chester County, Pennsylvania: EPA work assignment number 37-18-3625.

Keys, W.S., 1990, Borehole geophysics applied to ground-water investigations: U.S. Geological Survey Techniques of Water-Resources Investigations, book 2, chap. E2, $150 \mathrm{p}$.

Sloto, R.A., 1994, Geology, hydrology, and ground-water quality of Chester County, Pennsylvania: Chester County Water Resources Authority Water Resources Report 2, 118 p. 